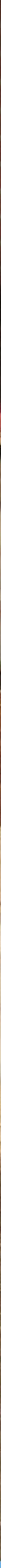

Inventariseren van mogelijke signaalindicatoren voor klimaat in Leghenstallen 



\section{Inventariseren van mogelijke signaalindicatoren voor klimaat in leghenstallen}

T.G.C.M. van Niekerk, H. Hopster

Wageningen Livestock Research

Dit onderzoek is uitgevoerd door Wageningen Livestock Research, in opdracht van en gefinancierd door het Ministerie van Landbouw, Natuur en Voedselkwaliteit, in het kader van het Beleidsondersteunend onderzoek thema 'Integraal Duurzame Veehouderij, dierenwelzijn en diergezondheid' (projectnummer BO-43-013.01-027)

Wageningen Livestock Research

Wageningen, maart 2020

Rapport 1241 
Niekerk, T.G.C.M. van, H. Hopster, 2020. Inventariseren van mogelijke signaalindicatoren voor klimaat in leghenstallen. Wageningen Livestock Research, Rapport 1241.

Samenvatting NL Op basis van literatuuronderzoek en een brainstormsessie met experts is gezocht naar signaalindicatoren om te controleren of het klimaat in leghennenstallen zodanig is dat het welzijn van de dieren niet geschaad is. Aan de hand van de beschikbare kennis is een concept protocol opgesteld. Niet duidelijk is of dit protocol onderscheidend genoeg zal zijn om daadwerkelijk problemen te kunnen vaststellen. Drempelwaardes, zoals bijvoorbeeld hoeveel dieren met afwijkend gedrag acceptabel zijn, zijn ook onbekend. Het verdient dan ook aanbeveling om het protocol nader in de praktijk uit te testen en zo mogelijk door te ontwikkelen.

Summary UK A literature study and a brainstorm session with experts has been carried out to find signalling indicators to check if the climate in poultry houses for laying hens is on a level that welfare of the animals is not harmed. With the available knowledge a draft protocol has been made. It is unclear if this protocol will be distinctive enough to be able to detect problems. Thresholds, like for instance the number of birds with abnormal behaviour, are not available. It therefore is recommended to test and further develop this protocol under commercial circumstances.

Dit rapport is gratis te downloaden op https://doi.org/10.18174/518197 of op www.wur.nl/livestock-research (onder Wageningen Livestock Research publicaties).

\section{(C) 2020 Wageningen Livestock Research}

Postbus 338, 6700 AH Wageningen, T 03174839 53, E info.livestockresearch@wur.nl, www.wur.nl/livestock-research. Wageningen Livestock Research is onderdeel van Wageningen University \& Research.

Wageningen Livestock Research aanvaardt geen aansprakelijkheid voor eventuele schade voortvloeiend uit het gebruik van de resultaten van dit onderzoek of de toepassing van de adviezen.

Alle rechten voorbehouden. Niets uit deze uitgave mag worden vermenigvuldigd en/of openbaar gemaakt worden door middel van druk, fotokopie, microfilm of op welke wijze dan ook zonder voorafgaande toestemming van de uitgever of auteur.

Wageningen Livestock Research is NEN-EN-ISO 9001:2015 gecertificeerd.

Op al onze onderzoeksopdrachten zijn de Algemene Voorwaarden van de Animal Sciences Group van toepassing. Deze zijn gedeponeerd bij de Arrondissementsrechtbank Zwolle. 


\section{Inhoud}

$\begin{array}{ll}\text { Woord vooraf } & 5\end{array}$

$\begin{array}{ll}\text { Samenvatting } & 7\end{array}$

1

$\begin{array}{lr}\text { Inleiding } & 9\end{array}$

$\begin{array}{lll}1.1 & \text { Doelstelling project } & 9\end{array}$

$\begin{array}{ll}1.2 \text { Afbakening } & 10\end{array}$

$2 \quad$ Materiaal en methode $\quad 11$

2.1 HAS-Voorstudie 11

2.2 WLR-onderzoek 11

2.2.1 Brainstorm sessie $\quad 11$

3

$\begin{array}{ll}\text { Resultaten } & 12\end{array}$

3.1 Stalklimaat $\quad 12$

3.1.1 Temperatuur: $\quad 12$

3.1.2 Luchtcirculatie 14

$\begin{array}{ll}3.1 .3 \text { Relatieve luchtvochtigheid } & 15\end{array}$

$\begin{array}{ll}3.1 .4 \mathrm{CO}_{2} & 16\end{array}$

$\begin{array}{ll}3.1 .5 \mathrm{NH}_{3} & 17\end{array}$

$\begin{array}{ll}3.1 .6 \text { Stof } & 18\end{array}$

$\begin{array}{ll}3.1 .7 \text { Endotoxinen } & 19\end{array}$

$\begin{array}{ll}3.1 .8 \text { Licht } & 20\end{array}$

$\begin{array}{ll}3.1 .9 \text { Geluid } & 21\end{array}$

$\begin{array}{ll}3.1 .10 \text { Potentiele dierindicatoren } & 21\end{array}$

3.2 Mogelijke aanpak controle stalklimaat $\quad 24$

3.2.1 Protocol dierindicatoren $\quad 24$

$\begin{array}{ll}3.2 .2 \text { Registratie overige kengetallen } & 25\end{array}$

$\begin{array}{ll}3.2 .3 \text { Klimaatmetingen } & 26\end{array}$

$\begin{array}{ll}3.2 .4 & \text { Overige bepalingen }\end{array}$

4 Conclusies en aanbevelingen $\quad 28$

$\begin{array}{ll}\text { Literatuur } & 29\end{array}$

Bijlage 1 Enkele bepalingen voor leghennen uit Besluit houders van dieren 33

$\begin{array}{lll}\text { Bijlage } 2 & \text { Voorbeeld scoreformulier dierindicatoren } & 35\end{array}$ 



\section{Woord vooraf}

Het welzijn van dieren wordt voor een niet te onderschatten deel bepaald door het klimaat in hun omgeving. Het in de Wet dieren opnemen van doelvoorschriften voor klimaat in pluimveestallen (open normen) is aantrekkelijk omdat het de regeldruk reduceert en de pluimveehouder zijn eigen route mag kiezen om het gestelde doel te realiseren. De handhaver en de sector worden daarmee echter uitgedaagd om concreet vast te stellen of het wettelijk gestelde doel door de pluimveehouder is behaald. Klimaat bevat veel aspecten en de effecten op het dier zijn niet altijd direct waarneembaar.

In opdracht van het Ministerie van Landbouw, Natuur en Voedselkwaliteit heeft Wageningen Livestock Research onderzoek uitgevoerd naar signaalindicatoren voor ontoereikend stalklimaat in pluimveestallen. Dit rapport bevat het resultaat van een brainstormsessie met experts op het terrein van het stalklimaat en het welzijn van pluimvee. Dit als vervolg op een literatuurstudie van Hofmans (2018), waarin reeds de potentiele klimaat factoren en hun uitwerking op het welzijn van pluimvee aangegeven zijn. Waar sprake was van kennishiaten, is aanvullend literatuuronderzoek verricht.

Het onderzoek is verkennend van aard en uitgevoerd in nauwe samenwerking met de Nederlandse Voedsel- en Warenautoriteit. Het is gericht op het vinden van aanwijzingen voor het niet voldoen aan de norm voor stalklimaat in pluimveestallen. Uiteindelijk konden er slechts in zeer beperkte mate signaalindicatoren worden geformuleerd. Dit rapport geeft een goed overzicht van de stand van zaken en de witte vlekken in kennis.

Hans Hopster

Maart 2020 


\section{Samenvatting}

Het Besluit houders van dieren bevat een zogenoemde 'open norm' voor wat betreft het stalklimaat voor stallen waarin leghennen gehouden worden. Er wordt weliswaar aangegeven dat het stalklimaat niet schadelijk mag zijn voor het dier, maar er zijn geen concrete criteria en normen gedefinieerd op basis waarvan dit kan worden geëvalueerd. Dit maakt het zowel voor pluimveehouders als voor inspecteurs van de NVWA lastig om te bepalen of ze deze open norm in voldoende mate naleven. Eerder heeft onderzoek plaatsgevonden door WLR naar signaalindicatoren voor een schadelijk klimaat in varkensstallen. De indicatoren die in dit onderzoek naar voren zijn gekomen, bieden nu handvatten voor inspecteurs van de NVWA bij het beoordelen van het klimaat in varkensstallen. Inspecteurs van pluimveestallen hebben te kennen gegeven ook behoefte te hebben aan dergelijke handvatten voor het beoordelen van klimaat in legkipstallen.

Binnen de NVWA heeft een hbo-student gedurende een half jaar een systematische literatuurstudie uitgevoerd naar signaalindicatoren voor klimaat in leghenstallen (Hofmans, 2018). Dit onderzoek concludeert dat er onvoldoende (vergelijkbaar) onderzoek is verricht naar klimaat in legkipstallen om op basis van een literatuurstudie te kunnen komen tot criteria die bruikbaar zijn in bijvoorbeeld een inspectieprotocol voor inspecteurs van de NVWA.

WLR heeft als vervolg op het werk van Hofmans een inventarisatie en korte literatuurstudie uitgevoerd naar mogelijke signaalindicatoren voor klimaat in leghenstallen. $\mathrm{Er}$ is een kritische evaluatie van de door Hofmans uitgevoerde literatuurstudie verricht en er is aanvullende literatuur verzameld. In een workshop met onderzoekers en praktijkdeskundigen (waaronder sectorvertegenwoordiging) is gereflecteerd op de resultaten en zijn deze verder aangescherpt. Op basis daarvan is op enkele aspecten nog nadere informatie in de literatuur gezocht. Vervolgens is een lijst opgesteld van mogelijke metingen, beschikbare meetmethodieken en voorstellen voor te ontwikkelen meetmethodieken.

Op basis van literatuuronderzoek en de brainstormsessie met experts kan gesteld worden dat er een beperkt aantal signaalindicatoren is om te controleren of het klimaat zodanig is dat het welzijn van de dieren niet geschaad wordt. Aan de hand van de beschikbare kennis is een concept protocol opgesteld. Niet duidelijk is of dit protocol onderscheidend genoeg zal zijn om daadwerkelijk welzijnsproblemen te kunnen vaststellen. Drempelwaardes, zoals bijvoorbeeld hoeveel dieren met afwijkend gedrag acceptabel zijn, zijn nog onbekend. Het verdient dan ook aanbeveling om het protocol nader in de praktijk uit te testen en zo mogelijk door te ontwikkelen. 


\section{$1 \quad$ Inleiding}

De wettelijke normen voor het houden van leghennen zijn opgenomen in het Besluit houders van dieren. In dit besluit staan duidelijke, cijfermatige normen voor zaken zoals ruimte per dier, voerbaklengte, en dergelijke. Hoewel er ten aanzien van het klimaat een aantal criteria genoemd worden, bevat het besluit geen harde wettelijke norm voor het klimaat in stallen waar legkippen worden gehouden. In bijlage 1 worden de artikelen uit het Besluit houders van dieren gegeven, die betrekking hebben op het klimaat in legstallen. Artikel 2.5 lid 4 van het Besluit houders van dieren bevat een zogenoemde 'open norm': "De luchtcirculatie, het stofgehalte van de lucht, de temperatuur, de relatieve luchtvochtigheid en de gasconcentraties in de omgeving van het dier zijn niet schadelijk voor het dier."

Er zijn geen concrete criteria en normen gedefinieerd op basis waarvan kan worden geconcludeerd dat het stalklimaat schadelijk is voor het dier. Dit geeft veehouders weliswaar de vrijheid om te kiezen op welke wijze ze aan de open norm voldoen, maar maakt het voor hen en voor inspecteurs van de NVWA tegelijkertijd lastig om te bepalen of ze deze open norm in voldoende mate naleven.

Er zijn zo'n 850 legkippenbedrijven in Nederland, die qua houderijsysteem/stalinrichting variëren. Legkippen zitten, in vergelijking met vleeskuikens, relatief lang in een stal (ongeveer anderhalf jaar). Bij vleeskuikens wordt een aantal keren per jaar (tussen de rondes door) de stal schoongemaakt en de vloer bedekt met vers strooisel. Doordat leghennen zo lang in de stal verblijven, gebeurt dit daar slechts eenmaal per circa 1,5 jaar. Het gevolg is een groter risico op een schadelijk stalklimaat door met name (fijn)stof.

Eerder heeft onderzoek plaatsgevonden door WLR naar signaalindicatoren voor een schadelijk klimaat in varkensstallen. De indicatoren die in dit onderzoek naar voren zijn gekomen, bieden nu handvatten voor inspecteurs van de NVWA bij het beoordelen van het klimaat in varkensstallen. Inspecteurs van pluimveestallen hebben te kennen gegeven ook behoefte te hebben aan dergelijke handvatten voor het beoordelen van klimaat in legkipstallen.

Binnen de NVWA heeft een hbo-student gedurende een half jaar een systematische literatuurstudie uitgevoerd naar signaalindicatoren voor klimaat in leghenstallen (Hofmans, 2018). Dit onderzoek concludeert dat er onvoldoende (vergelijkbaar) onderzoek is verricht naar klimaat in legkipstallen om op basis van een literatuurstudie te kunnen komen tot criteria die bruikbaar zijn in bijvoorbeeld een inspectieprotocol voor inspecteurs van de NVWA.

$\mathrm{Er}$ is behoefte aan het vergaren van kennis over welke signaalindicatoren in de praktijk gebruikt zouden kunnen worden als startpunt voor nader onderzoek naar de mate waarin legpluimveehouders het wettelijk gestelde stalklimaatdoel naleven.

\subsection{Doelstelling project}

Dit project is bedoeld als voorbereiding op een vervolgstudie naar het vinden van signaalindicatoren die duiden op een voor leghennen schadelijk stalklimaat. Dit kunnen omgevingsindicatoren zijn, maar ook dierindicatoren (gedrag of andere waarnemingen aan het dier).

De tussenstappen om tot dit doel te komen zijn:

1. Literatuurstudie naar mogelijke signaalindicatoren voor klimaat in leghennenstallen.

2. Inventariseren van mogelijke signaalindicatoren voor klimaat in leghenstallen.

a. Opstellen lijst vanuit de literatuurstudie.

b. Geëvalueerd door praktijkdeskundigen met zo nodig aanscherping.

3. Bepaling algemene signaalindicatoren die voor alle houderijsystemen gelden

4. Bepaling houderij-specifieke signaalindicatoren.

5. Interne evaluatie met deskundigen aangaande een wetenschappelijk verantwoorde en praktisch haalbare meetmethodiek voor de uit de inventarisatie voorgekomen mogelijke signaalindicatoren.

6. Ervaring opdoen met de ontwikkelde signaalindicatoren in praktijkstallen. 
Stap 1 en 2a zijn door de genoemde HBO-studente reeds voorbereid (Hofmans, 2018). Het onderhavige project heeft kort gekeken in hoeverre er nog missende informatie was, die kon worden toegevoegd en heeft het vervolg $\mathrm{t} / \mathrm{m}$ stap 4 uitgevoerd.

Afhankelijk van beschikbaarheid van budget en van de bevindingen van stap $2 \mathrm{t} / \mathrm{m} 4$ zal voor stap 5 een nieuw plan geschreven worden.

\subsection{Afbakening}

Het onderzoek is (met name) gericht op signaalindicatoren als direct gevolg van luchtcirculatie, stofgehalte, temperatuur, relatieve luchtvochtigheid en gasconcentraties die duiden op een voor de dieren schadelijke omgeving. Als indicatoren voor overschrijding van de norm is gekozen uit waarnemingen aan het dier of aan de omgeving van het dier. Randvoorwaarde is dat de indicator een bewezen relatie heeft met welzijn/gezondheid van het dier en meetbaar moet zijn voor inspecteurs van de NVWA tijdens een inspectie in de stal.

Hoewel de signaalindicatoren in principe voor alle houderijsystemen zouden moeten gelden, is de verwachting dat de klimaatproblematiek per houderijsysteem zal verschillen. Naast de problematiek van (fijn)stof die bij alle scharrelsystemen geldt, worden de grootste knelpunten verwacht bij traditionele scharrelsystemen met een mestput (hoge $\mathrm{NH}_{3}$-gehaltes) en systemen met buitenuitloop (via uitloopopeningen sterke beïnvloeding van het binnenklimaat). In eerste instantie zal het project zich dan ook op die systemen richten. Verbreding naar alle houderijsystemen zal in de meeste gevallen vanzelf gaan, omdat de indicatoren vaak systeem-onafhankelijk zijn. Daar waar er wel invloed van het systeem is, zal dit worden aangegeven. Indien uitwerking van de indicatoren voor de andere systemen noodzakelijk is, zal dit in een vervolgproject dienen te gebeuren. 


\section{Materiaal en methode}

\section{$2.1 \quad$ HAS-Voorstudie}

Recent is een stagerapport verschenen getiteld "Handhaving van open normen rondom dierenwelzijn" (Hofmans, 2018), met als ondertitel "De bepaling van signaalindicatoren voor een ontoereikend stalklimaat op legkipbedrijven; Een systematische literatuurstudie". In het rapport zijn door middel van een literatuurstudie signaalindicatoren geïdentificeerd, die de handhaver kunnen helpen bij de controle op naleving van de wettelijk gestelde doelen voor stalklimaat. Hierbij is geprobeerd om alle aspecten van het stalklimaat in relatie te brengen tot dierindicatoren. Ook zijn samen met inspecteurs stalbezoeken afgelegd om zo de mogelijkheden en onmogelijkheden van bepaalde signaalindicatoren beter in kaart te brengen. Daarbij is uitgegaan van de praktische randvoorwaarden, dat metingen en waarnemingen binnen de beschikbare middelen en tijd door de inspecteur uit te voeren moeten kunnen zijn.

De resultaten van de literatuurstudie geven aan dat er schadelijke effecten van het stalklimaat op kippen gevonden zijn en dat er voor een aantal aspecten van het stalklimaat signaalindicatoren zijn. Echter, er zijn heel weinig bepalingen, die als signaalindicator kunnen dienen. De uit deze literatuurstudie bewezen correlaties tussen de verschillende aspecten van het stalklimaat geven daarnaast aan dat het stalklimaat een resultante is van verschillende factoren die elkaar onderling beïnvloeden. Dat maakt het lastig om het stalklimaat te kunnen beoordelen op basis van enkelvoudige factoren. Er moet altijd naar het geheel aan omstandigheden gekeken worden om conclusies te kunnen trekken. In het rapport worden vervolgens enkele aanbevelingen gedaan voor vervolgonderzoek, die zich vooral richten op optimalisatie van ventilatie, nader inzicht in de schadelijke effecten van stof en een beter inzicht in de gedragsindicatoren van de kippen.

\section{$2.2 \quad$ WLR-onderzoek}

Het project is in drie stappen uitgevoerd.

1. Met de literatuurstudie van de NVWA stagiaire als vertrekpunt is de literatuur op specifieke punten nader uitgediept.

2. Via een brainstorm met experts zijn de resultaten van de literatuurstudie van de stagiaire en de eigen aanvullingen hierop bediscussieerd en zijn van een aantal specifieke klimaatfactoren de te verwachten effecten op het dier in kaart gebracht.

3. Voor de uit punt 1 en 2 naar voren gekomen effecten is een lijst opgesteld van mogelijke metingen, beschikbare meetmethodieken en voorstellen voor te ontwikkelen meetmethodieken.

\subsubsection{Brainstorm sessie}

Op 12-12-2018 is een brainstormsessie gehouden. Er waren 10 personen aanwezig. Het betrof 2 personen van de NVWA, 1 persoon vanuit LNV, 1 persoon vanuit de Dierenbescherming, 1 sectorvertegenwoordiger (legpluimveehouder) en 1 sector-expert (licht- en klimaatexpert) en 4 onderzoekers van WLR (2 dierenwelzijn-experts en 2 klimaatexperts).

Tijdens de brainstormsessie zijn alle klimaataspecten, die in het stagiairerapport benoemd zijn, de genoemde indicatoren en de aanvullingen vanuit eigen expertise en literatuuronderzoek bediscussieerd. Per indicator is bekeken wat de relatie is met het betreffende klimaataspect en of de indicator specifiek genoeg is om problemen bij dit klimaataspect te kunnen aangeven. Aanvullende indicatoren zijn genoemd en volgens dezelfde norm geëvalueerd.

Alle informatie uit de brainstormsessie is in een verslag verwerkt, dat vervolgens ter beoordeling aan de deelnemers gezonden is. De aanvullingen en opmerkingen die genoemd werden zijn verwerkt. Het verslag is in dit rapport verwerkt. Waar vragen waren is nader literatuuronderzoek uitgevoerd. 


\section{Resultaten}

\subsection{Stalklimaat}

Stalklimaat bestaat uit verschillende factoren die in figuur 3.1 in drie groepen verdeeld zijn. Deze indeling geeft drie hoofdaspecten van klimaat aan: 1. Luchtsamenstelling: de gassen, geuren, stof en kiemen in de lucht; 2. Klimaatcondities: de factoren waardoor het klimaat beïnvloed kan worden (temperatuur, ventilatie en luchtsnelheid); 3. Overige klimaataspecten (licht, geluid). Deze laatste groep bevat strikt genomen geen klimaatfactoren, maar ze worden doorgaans wel onder deze noemer meegenomen ${ }^{1}$.
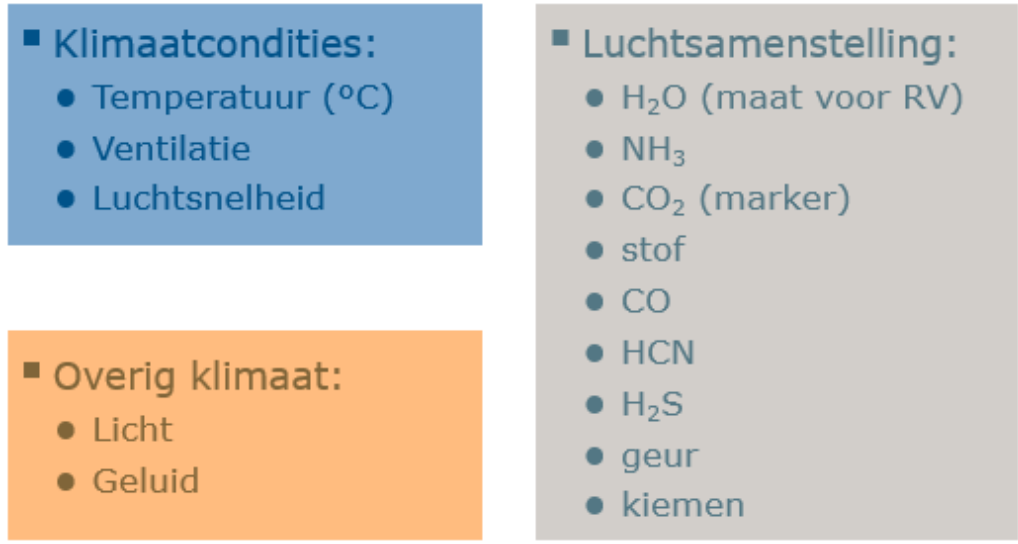

Figuur 3.1 Factoren die onderdeel uitmaken van het stalklimaat in leghennenstallen.

Elke factor is in de workshop bediscussieerd aan de hand van de in het stagerapport van Hofmans (2018) aangegeven dierindicatoren, aangevuld met informatie uit eigen literatuuronderzoek. In onderstaande paragrafen wordt steeds eerst de tabel weergegeven, waarmee de discussie begonnen is. Deze tabel bestaat steeds uit een linker kolom met omgevingsindicatoren, die via een korte literatuurstudie verzameld zijn, en een rechter kolom met dierindicatoren, zoals in het verslag van Hofmans (2018) aangegeven zijn. Vervolgens wordt enige achtergrondinformatie op basis van de literatuur gegeven. Daarna worden de aanvullende opmerkingen uit de workshop genoemd en dan de uiteindelijke tabel als resultaat van de discussie.

\subsubsection{Temperatuur:}

\section{Startpunt discussie:}

\begin{tabular}{ll} 
Omgevingsindicatoren & Dierindicatoren \\
Thermoneutrale zone: & Voer- en wateropname \\
$-\quad 15-26^{\circ} \mathrm{C}$ & Lichaamsgewicht \\
Optimaal voor productie: & Uitval \\
$-\quad 18-21^{\circ} \mathrm{C}$ (scharrelstal) & Huddling \\
$-\quad 18-20^{\circ} \mathrm{C}$ (volière) & Hijgen \\
\hline
\end{tabular}

\section{Achtergrondinformatie:}

De optimale temperatuur voor productie is meer gezien vanuit de pluimveehouder, d.w.z. een optimum voor wat betreft voerverbruik en eiproductie (Al-Saffar and Rose 2002).

\footnotetext{
${ }^{1}$ Deze aspecten vallen niet onder de wettelijke bepalingen met betrekking tot klimaat (art. 2.5 lid 4 Besluit houders van dieren). Voor licht is een aparte bepaling van toepassing: art. 2.5 lid 1 Besluit houders van dieren. Voor legkippen in het bijzonder in art. 2.75 Besluit houders van dieren. Voor wat betreft geluid is bij legkippen art. 2.73 lid 1 van toepassing.
} 
De invloed van temperatuur kan eigenlijk niet los gezien worden van de relatieve luchtvochtigheid en de luchtsnelheid, omdat deze een sterke invloed hebben op de 'gevoelstemperatuur', dus hoe de kip de temperatuur daadwerkelijk ervaart (Chepete and Xin 2004; Karaman et al. 2007; Ruzal et al. 2011). Ook de bezettingsdichtheid en daarmee de mogelijkheden voor het dier om warmte kwijt te raken, zijn van groot belang voor het bepalen van de temperatuurzone, waarin het dier normaal kan functioneren (Holik 2009; Weeks et al. 1997).

Diverse auteurs geven aan dat er eigenlijk geen duidelijke thermoneutrale zone is voor pluimvee, omdat veel aspecten (zoals b.v. voeropname, zuurstofgebruik) gradueel wijzigen met de temperatuur en er geen thermo-range aan te geven is, waarin deze aspecten gelijk blijven (Al-Saffar and Rose 2002; Arieli et al. 1979, 1980; Hooper and Richards 1991; Kampen et al. 1979).

Aerts et al. (2004) noemen als thermoneutrale zone $15-26^{\circ} \mathrm{C}$. Exacte cijfers zijn echter moeilijk te geven, omdat het sterk afhangt van de relatieve luchtvochtigheid en luchtsnelheid rond het dier enerzijds en de mate van bevedering anderzijds. Meltzer et al. (1982) geven voor opfokleghennen ouder dan 8 weken als thermoneutrale zone 22 tot $27^{\circ} \mathrm{C}$ aan. Dit komt overeen met Van Kampen et al. (1979), die voor volwassen leghennen 22.3 tot $27.5^{\circ} \mathrm{C}$ vonden. Zij gaven ook aan dat kippen pas gaan hijgen bij een omgevingstemperatuur van $29^{\circ} \mathrm{C}$. Al-Saffar and Rose (2002) berekenden op basis van 29 gepubliceerde onderzoeken het effect van de omgevingstemperatuur op voeropname, eiproductie, lichaamsgewicht en diverse ei-karakteristieken. Zij vonden bij 28 à $30^{\circ} \mathrm{C}$ een sterke afname van de eiproductie, voeropname en schaalsterkte en gaven aan dat vanaf dit punt sterk hijgen en hittestress optreedt, hetgeen in lijn is met Van Kampen et al. (1979). Arieli et al. (1979) geven daarbij aan dat er acclimatisering optreedt, zodat het dier zich aan de omgevingstemperatuur aanpast en er dus geen vaste waarden voor de thermoneutrale zone te geven zijn. Volgens Arieli et al. (1980) geldt dit vooral voor de ondergrens en minder voor de hogere temperatuurgrens. Bij deze bovengrens vonden ze dat tot $32^{\circ} \mathrm{C}$ acclimatisering optreedt, maar dat vanaf die temperatuur alle hennen hittestress vertoonden, ongeacht acclimatisering. Ook Hooper and Richards (1991) vonden rond $32^{\circ} \mathrm{C}$ een sterke stijging van de ademhalingsfrequentie en een grotere bereidheid van de hennen om te werken voor een koelere omgeving.

Dayyani and Bakhtiari (2013) maken onderscheid tussen langzaam hijgen bij matige hittestress en snel hijgen bij sterke hittestress. Ook geven zij enkele andere gedragskenmerken van hittestress: naar adem happen, lethargie en traagheid, gesloten ogen, liggen.

Bij koude omstandigheden, vooral in vrieskoude, blijken hennen meer te gaan zitten met bol opgezette veren (Hooper and Richards 1991). Verder tast het verblijven onder langdurige koude de immuniteit van de dieren aan en zullen ze daardoor eerder vatbaar zijn voor ziekten (Campo et al. 2008; Hooper and Richards 1991). In hoeverre de dieren stress ondervinden van de koude kan per genotype verschillen (Spinu and Degen 1993).

\section{Aanvullingen vanuit de brainstorm met experts:}

- Directe dierindicatoren met betrekking tot temperatuur zijn: huddling (bij koude) en hijgen (bij warmte). Hieraan kan nog toegevoegd worden: houding (met de vleugels wijd zitten om warmte kwijt te raken).

- Voeropname zal dalen bij warm weer en stijgen bij koud weer. Wateropname zal stijgen bij warm weer. Het lichaamsgewicht zal bij een lagere voeropname kunnen dalen, maar in legstallen worden bijna geen dierwegingen gedaan.

- Uitval kan toenemen bij extreme warmte (Dayyani and Bakhtiari 2013) of kou (dit laatste echter m.n. tijdens transport (Weeks et al. 2012)).

- Voer- en wateropname en uitval kunnen ook door andere (klimaat)factoren beïnvloed worden en zijn dus op zich niet direct een aanwijzing voor een temperatuurprobleem. Ze kunnen wel gebruikt worden om te bepalen of een temperatuurprobleem incidenteel is of een meer langdurig karakter heeft: bij incidentele problemen zullen voer- en wateropname, zoals op een computer of hokkaart uit te lezen is, geen afwijkingen vertonen en zal een verhoogde uitval niet meerdere dagen aanhouden.

- De temperatuur die de klimaatcomputer aangeeft is geen goede indicator. Wel zou de temperatuurverdeling in de stal, af te lezen aan de diverse voelers een redelijk beeld kunnen geven van een temperatuurprobleem.

- Eventueel kan 's nachts gekeken worden in bijvoorbeeld een 2-etage stal. De onderste etage kan tocht over de bovenste laag zitstokken hebben, vooral als er weinig ruimte is tussen de 
zitstokken en de vloer van de bovenste etage. De hennen zullen hier dan niet graag gaan zitten.

- Mogelijke effecten op eieren? De schaalkwaliteit kan bij langdurige hoge temperaturen slechter worden (Al-Saffar and Rose 2002).

- De overdekte uitloop wordt vaak wel tot het beschikbare leefoppervlak gerekend. Moet de temperatuur daar dan ook gemeten worden? Nee, deze zal naar verwachting zeer variabel zijn door de grote invloed van het buitenklimaat. Het is dan niet reëel om dit mee te tellen.

$\begin{array}{ll}\text { Indicatoren en aandachtspunten Temperatuur: } \\ \text { Signaalindicatoren } & - \text { Huddling } \\ & - \text { Hijgen } \\ \text { Vervolgindicatoren } & - \text { Voergels wijd uit } \\ & - \text { Lichaamsgewicht } \\ & - \text { Uitval } \\ & - \text { Demperatuurverdeling in de stal } \\ \text { Attentiepunten } & - \text { Temperatuur op zich zegt niet veel, hoe het dier deze ervaart } \\ & - \text { hangt mede af van RV en luchtsnelheid } \\ & - \text { Er dient altijd gekeken te worden naar de combinatie } \\ & \end{array}$

\subsubsection{Luchtcirculatie}

Startpunt discussie:

\begin{tabular}{|c|c|c|}
\hline \multicolumn{2}{|c|}{ Omgevingsindicatoren } & Dierindicatoren \\
\hline \multicolumn{2}{|c|}{$\begin{array}{ll}- & \text { Tocht } \\
- & \text { Advies: }\end{array}$} & Ademhalingsproblemen \\
\hline & Ventilatiecapaciteit: & Eiproductie \\
\hline & $\begin{array}{l}\quad \quad \text { Min: } 0,7 \mathrm{~m}^{3} / \mathrm{kg} / \mathrm{uur} \\
\quad \operatorname{Max} \cdot 36-4 \mathrm{~m}^{3} / \mathrm{kg} / \mathrm{rur}\end{array}$ & Voeropname \\
\hline 。 & $\begin{array}{l}\text { Luchtsnelheid: } \\
\text { - } \quad \max .0,25 \mathrm{~m} / \mathrm{s}\end{array}$ & Wateropname \\
\hline
\end{tabular}

\section{Achtergrondinformatie:}

De aangegeven ventilatiecapaciteit is gebaseerd op mechanische ventilatie via lengte en/of nok, luchtinlaat via ventielen, zonder verdiepingen (Klimaatplatform Pluimveehouderij, 2019). Doorgaans wordt de ventilatiehoeveelheid bepaald via klimaatcomputers, die reageren op de door diverse voelers gemeten luchttemperatuur. Op basis van deze informatie worden ventilatoren aangestuurd en wordt de grootte van luchtinlaten bepaald. De meer geavanceerde klimaatregeling meet naast de staltemperatuur ook de relatieve luchtvochtigheid en stuurt het klimaat op basis van beide waarden (Pedersen et al. 1998). Metingen gedurende twee jaar aan twee grote leghennenstallen in de VS gaven aan dat de ventilatie varieerde van 0,59 tot 5,01 $\mathrm{m}^{3} / \mathrm{kg} / \mathrm{uur}$, hetgeen aangeeft dat de ventilatierange in de praktijk breder kan zijn, dan die in het hierboven aangegeven advies voor installatie (Chai et al. 2012).

Bij natuurlijke ventilatie kunnen wel de luchtinlaten groter of kleiner gemaakt worden, maar is er geen mogelijkheid tot mechanische luchtbeweging. Hierdoor zijn de mogelijkheden om bij hoge buitentemperaturen een acceptabele staltemperatuur te realiseren beperkt (Gurdil 2009).

De aangegeven maximale luchtsnelheid gaat uit van het voorkómen van tocht bij de dieren. Echter, bij hoge omgevingstemperaturen kan een hogere luchtsnelheid dan het hier aangegeven maximum de dieren helpen bij hun thermoregulatie en dus juist positief zijn voor de dieren.

E.Coli is een secundaire infectie die vaak optreedt bij verminderde weerstand (Voeten 2000).

Chronische E.Coli kan een indicatie zijn van een slecht stalklimaat (Zanella et al. 2000).

\section{Aanvullingen vanuit de brainstorm met experts:}

- Bij de aangegeven minimumventilatie van $0,7 \mathrm{~m}^{3} / \mathrm{kg} / \mathrm{uur}$ is de kans groot dat de concentratie $\mathrm{NH}_{3}$ veel te hoog wordt. Het geadviseerde minimum ventilatiedebiet is niet persé ideaal voor de luchtkwaliteit. Verder gaat het hier vaak om de geïnstalleerde capaciteit, niet om de werkelijk gemeten debieten.

- Bij continue slechte luchtcirculatie kan E.Coli optreden. 
- $\quad$ Als E.Coli optreedt, is niet echt aan te geven hoeveel \% toebedeeld kan worden aan klimaat. Het is aannemelijk dat een secundaire infectie met E.Coli bij luchtwegproblemen meer optreedt in najaar en voorjaar (bij vochtige omstandigheden) en E.Coli als gevolg van een hoge vogelmijtdruk meer in de zomer (bij warme temperaturen vermenigvuldigt de vogelmijt zich sneller en is de infectiedruk doorgaans hoger (Kilpinen et al. 2005; Kowalski and Sokol 2009; Sparagano et al. 2009)).

- $\quad B i j$ tocht op het legnest kunnen hennen een andere plek gaan zoeken om hun ei te leggen en kan het percentage buiten-nest-eieren (BNE) toenemen.

- Hoesten en proesten zijn aanwijzingen van luchtcirculatieproblemen (David et al. 2015). Bij varkens is er de hoestsensor (Stokkermans, 2017). Geluid van de dieren is sowieso een goede indicator, maar dan moet wel duidelijk zijn welk geluid.

- $\quad$ Er is geen directe indicator van slechte luchtcirculatie. Dit dient afgeleid te worden uit een combinatie van waarnemingen.

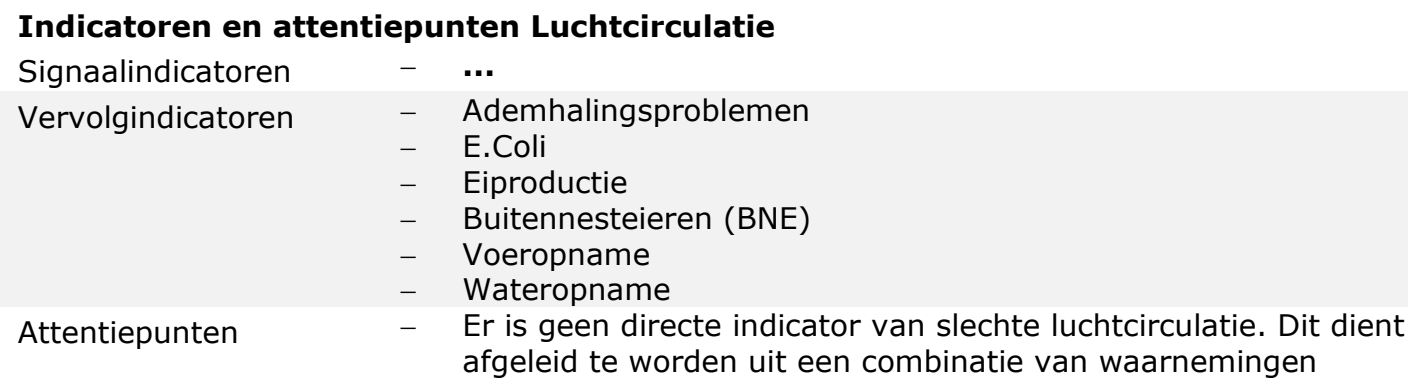

\subsubsection{Relatieve luchtvochtigheid}

\section{Startpunt discussie:}

\begin{tabular}{cl} 
Omgevingsindicatoren & Dierindicatoren \\
- Advies: $\quad 50 \%-70 \%$ (icm temp) & Voer- en wateropname \\
& Lichaamsgewicht \\
& Eiproductie \\
\hline
\end{tabular}

\section{Achtergrondinformatie:}

Zoals in de paragraaf over temperatuur al aangegeven is, heeft de RV een sterke invloed op hoe de omgevingstemperatuur ervaren wordt. Daarnaast heeft de RV een indirect effect op de gezondheid van pluimvee, doordat het de overleving van bacteriën, virussen en schimmels beïnvloedt (Xiong et al. 2017; Hoeksma et al. 2015). Bij een RV van 20-35\% zijn de omstandigheden ideaal voor het Influenzavirus om zich te verspreiden, terwijl dit bij $80 \%$ of meer volledig geblokkeerd wordt. Er is tevens een sterke relatie tussen de overleving van bacteriën zoals Escherichia coli en Salmonella en de RV, waarbij de ideale RV voor overleving $55-75 \%$ is. Dit is echter per type bacterie anders. Gramnegative bacteriën zoals Pseudomonadaceae overleven het beste bij een RV van meer dan 85\%. Ook Campylobacter soorten overleven het beste bij een hoge RV. Schimmels gedijen het beste bij een RV van $55-75 \%$ en de productie van mycotoxines is dan ook het hoogste. De ideale luchtvochtigheid voor pluimvee ligt echter tussen 50 en $70 \%$, hetgeen dus ongeveer gelijk is aan de omstandigheden waaronder de meeste ziektekiemen overleven.

\section{Aanvullingen vanuit de brainstorm met experts:}

- $\quad$ Een te lage RV resulteert in meer stof en daardoor wellicht meer ademhalingsproblemen (Huneau-Salaun et al. 2011).

- Te hoge RV kan resulteren in condens en nat strooisel, ook door verkeerde luchtbeweging.

- Een hoge RV kan resulteren in hijgen als het in combinatie is met een hoge temperatuur.

- $\quad$ RV kan niet los gezien worden van temperatuur en luchtbeweging. 


\section{Indicatoren en attentiepunten RV:}

\begin{tabular}{|c|c|c|}
\hline Signaalindicatoren & - & Hijgen \\
\hline Vervolgindicatoren & $\begin{array}{l}- \\
- \\
-\end{array}$ & $\begin{array}{l}\text { Ademhalingsproblemen } \\
\text { Hoesten en proesten, geluid van de dieren } \\
\text { Nat strooisel }\end{array}$ \\
\hline Attentiepunten & - & RV kan niet los gezien worden van temperatuur en luchtbeweging \\
\hline
\end{tabular}

\subsection{4 $\quad \mathrm{CO}_{2}$}

Startpunt discussie:

\begin{tabular}{ll} 
Omgevingsindicatoren & Dierindicatoren \\
Advies: & Hijgen (ook temp) \\
$<2500 \mathrm{ppm}$ & Happen naar adem \\
& Hoofdschudden \\
& Spartelen \\
& Diergewicht \\
\hline
\end{tabular}

\section{Achtergrondinformatie:}

Als norm voor $\mathrm{CO}_{2}$ noemt het Klimaatplatform Pluimvee maximaal 2500 ppm. De grens waarboven daadwerkelijk problemen gaan optreden ligt echter veel hoger. Anderson et al. (1966) vonden bij vleeskuikens die 8 weken blootgesteld waren aan 5000 ppm geen schade aan de longen. Reece and Lott (1980) vonden bij vleeskuikens pas bij 12.000 ppm negatieve effecten op de groei.

Gedragingen die gezien worden bij hoge concentraties $\mathrm{CO}_{2}$ zijn spartelen, snelle snavelbewegingen en ontsnappen, happen naar adem en hoofdschudden (McKeegan et al. 2005).

$\mathrm{CO}_{2}$ is te meten met behulp van gasdetectiebuisjes. Het betreft hier dan een momentopname, maar het kan ook continu worden gemeten sensoren in de stal (https://slimmestal.nl/module-klimaat/). Om een beeld te krijgen van wat de dieren ervaren dient de meting in de buurt van de dieren plaats te vinden.

\section{Aanvullingen vanuit de brainstorm met experts:}

- $\mathrm{CO}_{2}$ concentratie is een goede indicator voor de mate van ventilatie/luchtverversing. Dit wordt ook door de EFSA aangegeven (de Jong et al.; EFSA 2005).

- Als norm voor maximale $\mathrm{CO}_{2}$ concentratie wordt door het klimaatplatform 2500 ppm genoemd. In de Europese wetgeving voor leghennen wordt geen grenswaarde genoemd, maar in de Broiler Directive (2007/043) wordt als bovengrens 3000 ppm ter hoogte van de kop van de kuikens genoemd (E.U. 2007).

- $\mathrm{CO}_{2}$ is vrij eenvoudig te meten, dus dit is beter dan te trachten iets aan de dieren af te leiden.

\section{Indicatoren en attentiepunten $\mathrm{CO}_{2}$ :}

Signaalindicatoren Vervolgindicatoren

Attentiepunten
$\mathrm{CO}_{2}$ concentratie in stallucht

- Hijgen (ook temp)

- Happen naar adem

- Hoofdschudden

- Spartelen

- Diergewicht

- $\mathrm{CO}_{2}$ is vrij eenvoudig te meten, dus $\mathrm{CO}_{2}$ meten om iets te kunnen zeggen over ventilatie/luchtverversing is beter dan in dat kader trachten iets aan de dieren af te leiden. 


\subsection{5 $\quad \mathrm{NH}_{3}$}

Startpunt discussie:

\begin{tabular}{ll} 
Omgevingsindicatoren & Dierindicatoren \\
Advies: & Ogen dichtknijpen \\
$<20 \mathrm{ppm}$ & Keratoconjunctivitis \\
& Respiratieproblemen \\
& Spartelen \\
& Vermijdingsreactie \\
& Voeropname \\
& Diergewicht \\
\hline
\end{tabular}

\section{Achtergrondinformatie:}

Volgens Naseem and King (2018) is de ideale concentratie $\mathrm{NH}_{3}$ beneden $10 \mathrm{ppm}$, maar tot $25 \mathrm{ppm}$ is deze niet schadelijk voor de gezondheid van mens en dier. Kristensen et al. (2000) vonden dat de grens waarop de concentratie $\mathrm{NH}_{3}$ aversief wordt, voor leghennen tussen 0 en $25 \mathrm{ppm}$ lag. Jones et al. (2005) geven aan dat vleeskuikens een niveau van $10 \mathrm{ppm}$ al aversief vinden.

Amer et al. (2004) geven aan dat eiproductie en schaalkwaliteit niet negatief werd beïnvloed bij een concentratie van $50 \mathrm{ppm}$ gedurende een periode van 4 weken. Bij $100 \mathrm{ppm}$ was de eiproductie wel verlaagd, alsmede voer- en wateropname en diergewicht.

Hoge concentraties leiden tot gedragsuitingen, zoals spartelen, snelle snavelbewegingen en ontsnappen (McKeegan et al. 2005).

\section{Aanvullingen vanuit de brainstorm met experts:}

- Volgens Nederlandse experts komen in leghennenstallen regelmatig veel hogere concentraties voor dan de genoemde $20 \mathrm{ppm}$. Dit komt overeen met de bevindingen van Kristensen and Wathes (2000), die daarbij aangaven dat uitschieters tot 40 ppm niet ongewoon zijn.

- Bij 20 ppm is doorgaans niet veel aan de dieren te zien, maar daarbij speelt mee dat er gewenning optreedt aan hoge niveaus van $\mathrm{NH}_{3} .20 \mathrm{ppm}$ is echter nog geen niveau waarop snel schade ontstaat (Naseem and King 2018).

- Keratoconjunctivitis is te herkennen aan ontstoken hoornvlies, met rode ogen en schijnt te gaan optreden indien de dieren blootgesteld worden aan concentraties $\mathrm{NH}_{3}$ boven $60-70 \mathrm{ppm}$ (Kristensen and Wathes 2000).

- Spartelen en vleugelslaan dienen gelezen te worden als pogingen tot ontsnappen; deze gedragingen zullen naar verwachting vooral optreden bij een plotselinge blootstelling aan hoge niveaus van $\mathrm{NH}_{3}$.

- De oogproblemen zijn typerend, worden niet door b.v. stof veroorzaakt, maar daadwerkelijk door $\mathrm{NH}_{3}$.

- Ogen dichtknijpen dient niet verward te worden met hennen die dommelen/slapen.

- Hoge concentraties $\mathrm{NH}_{3}$ kunnen oogschade en zelfs blindheid geven bij de dieren. Indirect kan dit opgemerkt worden door een verlaagde voeropname en hogere uitval, doordat blinde dieren het voer niet meer kunnen vinden (in volières kunnen ze niet meer op de etages komen).

\section{Indicatoren en attentiepunten $\mathrm{NH}_{3}$ :}

\begin{tabular}{|c|c|c|}
\hline Signaalindicatoren & & $\begin{array}{l}\mathrm{NH}_{3} \text {-metingen } \\
\text { Ogen dichtknijpen } \\
\text { Keratoconjunctivitis }\end{array}$ \\
\hline Vervolgindicatoren & $\begin{array}{l}- \\
- \\
-\end{array}$ & $\begin{array}{l}\text { Respiratieproblemen } \\
\text { Spartelen } \\
\text { Vermijdingsreactie } \\
\text { Voeropname } \\
\text { Diergewicht }\end{array}$ \\
\hline Attentiepunten & - & $\begin{array}{l}\mathrm{NH}_{3} \text { zal vooral hoog zijn bij lage ventilatieniveaus in de koude } \\
\text { jaargetijden }\end{array}$ \\
\hline
\end{tabular}




\subsubsection{Stof}

\section{Startpunt discussie:}

$\begin{array}{ll}\text { Advies leghennen: } & \text { Dierindicatoren } \\ <2 \mathrm{mg} / \mathrm{m}^{3} \text { respirabel stof } & \text { Respiratieproblemen } \\ \text { Advies mens: } & \text { Verminderde groei } \\ \text { - } \quad \text { gewogen gemiddelde over } 8 \text { uur: } & \\ \quad<3 \mathrm{mg} / \mathrm{m}^{3} \text { respirabel stof } & \\ <10 \mathrm{mg} / \mathrm{m}^{3} \text { inhaleerbaar } & \\ \text { gewogen gemiddelde over } 15 \mathrm{~min} .: & \\ <6 \mathrm{mg} / \mathrm{m}^{3} \text { respirabel stof } & \\ <20 \mathrm{mg} / \mathrm{m}^{3} \text { inhaleerbaar } & \end{array}$

\section{Achtergrondinformatie:}

Stof, doorgaans fijnstof (deeltjes $<10 \mu \mathrm{m}$ ) genoemd, is een verzamelnaam voor deeltjes in de lucht. De herkomst van deze deeltjes in een pluimveestal is strooisel, mest, veren en voer. Bij pluimvee leveren met name mest en veren de grootste bijdrage aan fijnstof (Cambra-López et al. 2011). Fijnstof bevat ook kiemen, die de gezondheid van mens en dier nadelig kunnen beïnvloeden. Deze kiemen kunnen bacteriën, virussen, schimmels en/of endotoxinen zijn (Le Bouquin et al. 2013). Fijnstof bestaat uit deeltjes van verschillende grootte, waarbij de kleinere deeltjes verder in de longen kunnen doordringen en daardoor potentieel schadelijker zijn. Er worden verschillende klassen onderscheiden op basis van deeltjesgrootte: $\mathrm{PM}_{10}$ en $\mathrm{PM}_{2.5}$. PM staat voor de Engelse term voor stof: Particulate Matter. Het getal geeft de maximale diameter in micrometers aan. In de SER-adviezen voor de mens worden nog de termen 'respirabel stof'(deeltjes $<4 \mu \mathrm{m}^{2}$ ) en 'inhaleerbaar stof' (deeltjes $<100 \mu \mathrm{m}$ ) gehanteerd (Winkel 2018).

De Nederlandse wetgeving op het gebied van luchtkwaliteit is gebaseerd op de EU richtlijn 2008/50/EG (E.U., 2008). De luchtkwaliteitseisen en verplichtingen uit de Europese richtlijnen (inclusief de verkregen derogatie voor $\mathrm{PM}_{10}$ en $\mathrm{NO}_{2}$ ) zijn opgenomen in de Wet milieubeheer (hoofdstuk 5, titel $5.2 \mathrm{Wm}$; Wet Milieubeheer, 2019)). Het RIVM-dossier 'Fijn stof' (2013) is hierop gebaseerd en geeft aan dat voor $\mathrm{PM}_{10}$ in de buitenlucht de grenswaarde van $40 \mu \mathrm{g} / \mathrm{m}^{3}$ als jaargemiddelde niet mag worden overschreden en $50 \mu \mathrm{g} / \mathrm{m}^{3}$ als daggemiddelde op niet meer dan 35 dagen per jaar mag worden overschreden. Voor $\mathrm{PM}_{2.5}$ geldt de grenswaarde van $25 \mu \mathrm{g} / \mathrm{m}^{3}$ en vanaf 2020 een indicatieve grenswaarde van $20 \mu \mathrm{g} / \mathrm{m}^{3}$ als luchtkwaliteitsdoelstelling voor het jaargemiddelde. Dit zijn waarden voor blootstelling van de mens in de buitenlucht, voor pluimvee zijn (nog) geen grenzen.

\section{Aanvullingen vanuit de brainstorm met experts:}

- In stallen kan $10 \mathrm{mg} / \mathrm{m}^{3}$ voorkomen, hetgeen als hoog beschouwd wordt. $\mathrm{PM}_{10}$ niveaus liggen doorgaans op 7-8 $\mathrm{mg} / \mathrm{m}^{3}$ gemeten over 24 uur

- Uitval, respiratieproblemen kunnen door te hoge stofniveaus ontstaan, maar zijn ook gerelateerd aan andere klimaatkenmerken als T en RV.

\section{Indicatoren en attentiepunten Stof:}

$\begin{array}{lll}\text { Signaalindicatoren } & - & \text { Stofconcentratie } \\ \text { Vervolgindicatoren } & - & \text { Respiratieproblemen } \\ & - & \text { Verminderde groei } \\ \text { Attentiepunten } & - & \text { Uitval } \\ & - & \text { Er zijn geen puur specifieke signaalindicatoren, respiratieproblemen } \\ & & \text { zijn ook aan andere klimaatfactoren gerelateerd }\end{array}$

Het meten van stof is mogelijk met gespecialiseerde apparatuur. De door Welfare_Quality® (2009) gehanteerde methode is globaal en niet specifiek genoeg om als indicator voor een eventueel welzijnsprobleem te kunnen dienen.

Er is geen literatuur die een direct effect van stof op het gedrag en welzijn van pluimvee specificeert. Mede daarom zijn er geen signaalindicatoren bekend, die een exclusieve indicator zijn van een

\footnotetext{
${ }^{2}$ In het verleden werd als grens $5 \mu \mathrm{m}$ gehanteerd
} 
welzijnsaantasting als gevolg van stof. Een mogelijk schadelijk effect van stof kan dus niet direct gemeten worden, maar dient afgeleid te worden uit vervolgindicatoren en stofmetingen met gespecialiseerde apparatuur.

\subsubsection{Endotoxinen}

\section{Startpunt discussie:}

$\begin{array}{ll}\text { Omgevingsindicatoren } & \text { Dierindicatoren } \\ \text { Advies (mens): } & \text { Diergezondheid } \\ -\quad<30 \mathrm{EU} / \mathrm{m}^{3} & \text { Uitval }\end{array}$

\section{Achtergrondinformatie:}

De endotoxine blootstelling wordt uitgedrukt in Endotoxine Units $(\mathrm{EU}) / \mathrm{m}^{3}$. Bij mensen is bekend dat endotoxinen longproblemen veroorzaken (Winkel et al. 2014). De acute effecten worden waargenomen bij concentraties van $90 \mathrm{EU} / \mathrm{m}^{3}$ en hoger en zijn al vrij kort na blootstelling te zien. Vanaf $1000 \mathrm{EU} / \mathrm{m}^{3}$ treedt een temperatuursverhoging op en vanaf $2000 \mathrm{EU} / \mathrm{m}^{3}$ worden koortsachtige verschijnselen zichtbaar. Bij pluimveehouders zijn blootstellingen gemeten met gemiddeld gerapporteerde gehaltes tussen de 1000 en $10.000 \mathrm{EU} / \mathrm{m}^{3}$ (Winkel et al. 2014).

De geadviseerde maximale grenswaarde is gebaseerd op de gevonden grenswaarde van $90 \mathrm{EU} / \mathrm{m}^{3}$. Omdat bekend is dat kinderen, zwakke mensen en ouderen gevoeliger kunnen zijn, is de waarde verlaagd met een factor 3 tot $30 \mathrm{EU} / \mathrm{m}^{3}$, waaronder men ervan uitgaat dat mensen geen gezondheidsklachten meer krijgen. Deze grenswaarde geldt voor een blootstellingsduur van 8 uur (Winkel et al. 2014). Winkel et al. (2018) geven aan dat de geadviseerde grenswaarde betrekking heeft op de inhaleerbare stoffractie, maar dat er verschillende responsen kunnen optreden afhankelijk van waar in de luchtwegen depositie van endotoxinen plaatsvindt. Er is weinig informatie over depositie in de luchtwegen van deeltjes groter dan $10 \mu \mathrm{m}$. De gegevens die voorhanden zijn suggereren dat grotere deeltjes slechts in beperkte mate in de lagere luchtwegen zullen doordringen. Vooralsnog adviseren Winkel et al. (2018) om de metingen/grenswaarden voor fijnstof (PM 10$)$ aan te houden.

Uit onderzoek van Winkel et al. (2018) blijkt dat het endotoxinegehalte in het stof toeneemt met de deeltjesgrootte: grotere deeltjes zijn niet alleen zwaarder maar bevatten per eenheid van massa (mg) ook meer endotoxinen. Uitzondering hierop zijn de zeer kleine PM2,5 deeltjes, dat bij leghennen in verhouding juist weer wat meer endotoxinen bevatte. In stof uit legpluimveestallen zat gemiddeld circa $500 \mathrm{EU} / \mathrm{mg}$ endotoxinen (range: 60-911 EU/mg), waarbij de gehaltes 's nachts 2 à 3 keer zo hoog lagen. Er bleken met name 's nachts ook uitschieters voor te komen tot ruim $6000 \mathrm{EU} / \mathrm{mg}$. Verder is het endotoxinegehalte in pluimveestof een factor 3 tot 10 lager dan in varkensstof. Niet alleen tussen bedrijven, maar ook binnen een stal kan het endotoxinegehalte in het stof fors variëren.

\section{Aanvullingen vanuit de brainstorm met experts:}

- De genoemde $30 \mathrm{EU} / \mathrm{m}^{3}$ is voor stallen niet van toepassing. In binnenruimtes ligt het meer op $90 \mathrm{EU} / \mathrm{m}^{3}$. In varkensstallen kan een niveau van meer dan $1000 \mathrm{EU}$ voorkomen. Voor pluimveestallen is er onvoldoende kennis om een duidelijke grens te kunnen stellen. Vooralsnog zou deze grens aangehouden kunnen worden, waarboven problemen gaan optreden. Met behulp van gericht onderzoek moet dan bijstelling van deze grens plaatsvinden.

- Endotoxinen zijn celwandcomponenten van gram negatieve bacteriën. Bij inademing veroorzaken deze een (heftige) immuunreactie bij mens en dier. Daardoor kunnen er ziekteachtige verschijnselen optreden. Maar ze zijn niet echt ziekteverwekkend omdat ze zich niet kunnen vermeerderen in het lichaam. 


\section{Indicatoren en attentiepunten Endotoxinen:}

Signaalindicatoren

Vervolgindicatoren

Attentiepunten $\therefore$

Diergezondheid

Uitval

Er zijn geen puur specifieke signaalindicatoren

- Doordat endotoxinen via stof worden getransporteerd en niet alle stoffracties even diep in de longen doordringen, is het lastig om hiervoor richtlijnen op te stellen. Vooralsnog adviseren Winkel et al. (2018) om de metingen/grenswaarden voor fijnstof (PM $\left.\mathrm{M}_{10}\right)$ aan te houden

\subsubsection{Licht}

\section{Startpunt discussie:}

$\begin{array}{ll}\text { Omgevingsindicatoren } & \text { Dierindicatoren } \\ \text { Advies: } & \text { Oogaandoeningen } \\ >20 \text { lux? } & \text { Verminderde productie } \\ & \text { Schrikachtigheid } \\ & \text { Verenpikken }\end{array}$

\section{Achtergrondinformatie:}

Pluimvee heeft een goed zicht en kan kleuren goed onderscheiden. Het pluimvee-oog is in staat om UV-licht te zien. UV stelt de dieren in staat elkaar beter te herkennen en speelt ook een rol bij de preventie van verenpikkerij. De langere golflengtes (oranje/rood) zijn nodig om de hormoonproductie voor het leggen van eieren te stimuleren (Baxter et al. 2014). Deze golflengtes kunnen receptoren stimuleren die onder de schedel van de kip liggen (Niekerk et al. 2015).

In volièrestallen is licht van belang om de dieren in staat te stellen zich door het systeem te verplaatsen. Te lage lichtsterktes zullen ervoor zorgen dat de hen afstanden minder goed kan inschatten en bij het springen door het systeem vaker ten val zal komen (Moinard et al. 2004), hetgeen kan leiden tot botbreuken (Heerkens et al. 2016). O'Connor et al. (2011) vond bij 5 lux (versus 150 lux) en een geluidsniveau van $80 \mathrm{db}$ (versus $60 \mathrm{db}$ ) meer stress bij de dieren en daardoor een lagere eiproductie. Te hoge lichtniveaus worden vaak in verband gebracht met een toename in verenpikkerij, maar uit onderzoek blijkt dat hierbij de lichtkwalilteit een rol kan spelen: bij meer daglicht (wel of niet gefilterd door een raam) trad meer verenpikkerij op, maar bij meer daglicht met UV (niet gefilterd door een raam) bleek juist minder pikkerij op te treden (Reuvekamp and Niekerk 2010).

De lichtsterkte wordt weergegeven in lux. Dit is echter een maatlat, die gebaseerd is op het menselijk oog. Beter is het om de Gallilux te gebruiken, waarbij een correctie voor de gevoeligheid van het kippenoog is toegepast (Niekerk et al. 2015). Een Galliluxmeter is een speciale luxmeter, waarin een aantal extra lichtsensoren zitten, waardoor de metingen meer overeenkomen met de lichtgevoeligheid van het kippenoog. Vergelijkbaar met de berekening van de lux-waarde worden de metingen omgezet tot één meetwaarde, genaamd Gallilux (Lewis and Morris 2006). Het blijft echter één getal, dat niet volledig recht doet aan alle eigenschappen en karakteriseringen van licht.

Een belangrijk aspect is de flikkerfrequentie, die boven $120 \mathrm{~Hz}$ moet zijn, omdat de kippen het licht anders als flikkerend ervaren en daardoor gestresst kunnen raken (Lisney et al. 2012). Gloeilampen hebben geen flikkerfrequentie, laag-frequente TL-lampen geven wel een flikkering. Recent is LEDverlichting sterk in opkomst. Hoewel LED van zichzelf geen flikkerfrequentie heeft, kan de voorschakelapparatuur (met name het softwarematig dimmen) deze wel genereren (Niekerk et al. 2015). Er is lichtmeetapparatuur op de markt die ook de frequentie kan bepalen. Een eenvoudige manier (die echter niet altijd werkt) is het maken van een foto met een GSM. Bij een lage flikkerfrequentie zijn dan strepen in het beeld zichtbaar. Continu licht kan beschadigingen geven aan het oog van de kip (Li et al. 1995), maar is volgens de Europese wet verboden. 


\section{Aanvullingen vanuit de brainstorm met experts:}

- De genoemde 20 lux wordt in bepaalde regelgeving gehanteerd, maar heeft weinig wetenschappelijke onderbouwing.

- Lux is voor leghennen een weinig zeggende term, gallilux houdt al meer rekening met hetgeen een kip ziet. Uiteindelijk gaat het om meer dan alleen het aantal gallilux, dus bijv. ook het spectrum van het licht. Kippen zien UV-licht en kunnen de kleuren blauw en rood beter zien dan mensen.

- Hoewel een hoog lichtniveau niet per definitie verenpikkerij veroorzaakt, wordt bij pikkerijproblemen wel vaak het lichtniveau omlaag gebracht. Ook wordt wel overgegaan op rood licht. Dit zorgt ervoor dat details minder zichtbaar worden, waardoor bijvoorbeeld wonden minder zullen opvallen. Daarbij is niet duidelijk of altijd hetzelfde lichtniveau wordt aangehouden.

- Continu licht kan bij kippen oogproblemen geven. Continu licht is wettelijk echter niet toegestaan.

- $\quad$ Een te laag lichtniveau veroorzaakt een vermindering in eiproductie. Dit zal niet vaak voorkomen, omdat de grens erg laag ligt (minder dan 1 lux) en pluimveehouders hier wel alert op zijn.

- Bij lage lichtniveaus zijn hennen schrikachtiger. Ook bij licht met een lage frequentie (beneden $100 \mathrm{~Hz}$ ) kunnen kippen een mogelijke flikkering zien. Deze treedt niet alleen op bij laag-frequente TL-verlichting, maar ook bij bepaalde dimapparatuur van LED-verlichting.

\section{Indicatoren en attentiepunten Licht:}

Signaalindicatoren

Vervolgindicatoren

Attentiepunten
Lichtmeting (lux)

Oogaandoeningen

Verminderde productie

- Schrikachtigheid

- Verenpikken

- Er zijn geen puur specifieke signaalindicatoren

- $\quad$ Bij licht spelen vele aspecten een rol: lichtsterkte, lichtkleur en spectrum, lichtflikkeringen

\subsubsection{Geluid}

\section{Startpunt discussie:}

$\begin{array}{ll}\text { Omgevingsindicatoren } & \text { Dierindicatoren } \\ \text { Advies: } & \text { Verminderde productie } \\ \text { Max } 60 \mathrm{db} ? & \text { Schrikachtigheid } \\ & \text { Verenpikken/stress } \\ & \text { Uitval }\end{array}$

De genoemde $60 \mathrm{db}$ zou gelijk staan aan het geluidsniveau in een rustige kippenstal. In een lawaaiige kippenstal zou het geluidsniveau op circa 80db liggen (O'Connor et al., 2011).

\section{Indicatoren en attentiepunten Geluid:}

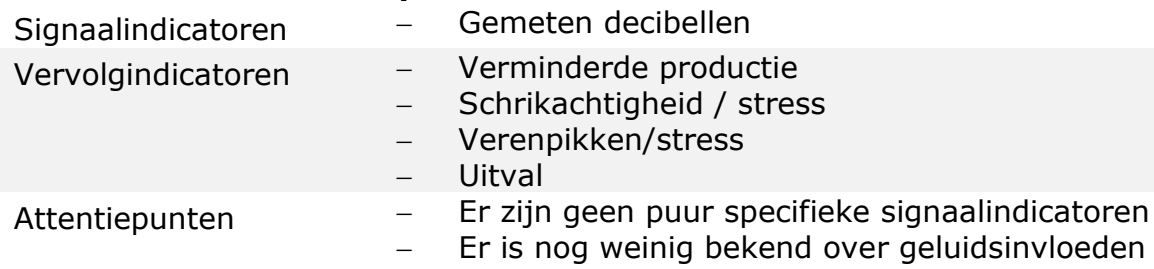

\subsubsection{Potentiele dierindicatoren}

Onderstaande tabel geeft een aantal dierindicatoren, die ook indicatief kunnen zijn voor klimaatproblemen, zoals in de voorgaande paragrafen aangegeven en ook in het verslag van Hofman (2018) genoemd zijn. Ze zijn onderverdeeld in metingen aan het individuele dier en metingen aan de groep of omgeving van het dier. Onder dat laatste valt bijvoorbeeld vogelmijt en parasieten. Indien 
deze aanwezig zijn, kan ervan uitgegaan worden dat dit zijn weerslag op de dieren zal hebben. Hokbevuiling, oppervlakte en inhoud van de stal per dier geeft aan in welke omgeving het dier functioneert. Een vuiler hok betekent meer risico op gezondheidsproblemen, meer ruimte geeft het dier meer mogelijkheden tot het uiten van soortspecifiek gedrag.

\begin{tabular}{lll}
\hline Metingen aan het individuele dier & & Overige \\
\hline Exterieur & Gedrag & Metingen/waarnemingen \\
Veerhygiëne & Houding & Uitval \\
Dierbevuiling & Hoesten, proesten, geluid & Voer- en wateropname \\
Kannibalisme & Ademhalingsproblemen & Eiproductie \\
Voetzooldermatitis & Hijgen & Lichaamsgewicht \\
Respiratieziekten & Happen naar adem & Verminderde groei \\
Oogaandoeningen (m.n. & Hoofdschudden & Darmgezondheid (mest) \\
Keratoconjunctivitis) & Spartelen & E.Coli \\
Veren- en kampikken & Vermijdingsreactie & Vogelmijt \\
Kam afwijkingen & Vleugels wijd uit & Parasieten (algemeen) \\
Oogscore & Drummen/Huddling & Hokbevuiling \\
& Ogen dichtknijpen & m ${ }^{3}$ per kip
\end{tabular}

(met aanpassingen naar: Hofmans, 2018)

Onderstaande tabellen geven een overzicht van de stalklimaat indicatoren en de mogelijke indicatoren, die daarop ingrijpen. $\mathrm{Er}$ is een opdeling gemaakt in dierindicatoren en stalindicatoren. De tabellen zijn gebaseerd op Hofmans (2018), aangevuld met de stalklimaatindicatoren Licht en Geluid en potentiele dierindicatoren. Met letters zijn relaties aangegeven waar dat relevant is:

- $\quad$ waar "S" staan zijn er directe relaties, hetgeen betekent dat indien de bewuste dierindicator waargenomen wordt, er een grote mate van zekerheid is dat de aangegeven stalklimaat-indicator suboptimaal is.

- $\quad$ waar een " $V$ " staat betreft het een vervolgindicator, hetgeen betekent dat er weliswaar een relatie bestaat tussen de stalklimaat- en dierindicator, maar dat deze niet exclusief is.

Ademhalingsproblemen kunnen bijvoorbeeld een indicatie zijn van suboptimaal klimaat, maar kunnen ook het gevolg zijn van een ziekte. Indien er op basis van een waargenomen dierindicator een vermoeden is dat een stalklimaat indicator niet optimaal is, kunnen additioneel de met $\mathrm{V}$ aangegeven dierindicatoren nagegaan worden om het vermoeden te bevestigen of ontkrachten. Anderzijds kan bij constatering van problemen bij een dierindicator een controle worden uitgevoerd van alle stalklimaat indicatoren, waarmee deze dierindicator een relatie heeft.

Wat opvalt in de tabellen is, dat er veel indirecte relaties zijn en weinig echte directe indicatoren. Deels wordt dit veroorzaakt door het feit dat deze indicatoren er niet zijn, maar deels ook met het ontbreken van kennis. 


\begin{tabular}{|c|c|c|c|c|c|c|c|c|c|}
\hline $\begin{array}{r}\text { Stalklimaat } \\
\text { indicatoren }\end{array}$ & 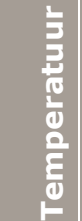 & 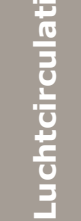 & $\stackrel{2}{*}$ & $8^{N}$ & 폴 & 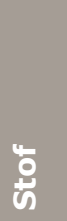 & $\begin{array}{l}\frac{5}{0} \\
\frac{1}{x} \\
0 \\
0 \\
\frac{0}{0} \\
\frac{0}{0}\end{array}$ & 름 & 흘 \\
\hline $\begin{aligned} \text { Houding } & \\
- & \text { Huddling } \\
- & \text { Vleugels spreiden }\end{aligned}$ & $\begin{array}{l}S \\
S\end{array}$ & & & & & & & & \\
\hline Hijgen & S & & $\mathrm{S}$ & V & & & & & \\
\hline Hoofdschudden & & & & V & & & & & \\
\hline Spartelen & & & & V & V & & & & \\
\hline Vermijdingsreactie & & & & & $\mathrm{V}$ & & & & \\
\hline Schrikachtigheid/stress & & & & & & & & v & $\mathrm{V}$ \\
\hline $\begin{array}{l}\text { Oog-beoordeling } \\
-\quad \text { ogen dichtknijpen } \\
-\quad \text { Keratoconjunctivitis } \\
-\quad \text { Oogaandoeningen }\end{array}$ & & & & & $\begin{array}{l}\mathrm{S} \\
\mathrm{S}\end{array}$ & & & v & \\
\hline $\begin{array}{l}\text { Dierbevuiling } \\
\quad \text { - veerhygiëne }\end{array}$ & & & & & & & & & \\
\hline Voetzooldermatitis & & & & & & & & & \\
\hline $\begin{array}{cl}\text { Ademhalingsproblemen } \\
\text { - } & \text { Happen naar adem } \\
\text { - } & \text { Respiratieziekten } \\
\text { - } & \text { Hoesten/proesten }\end{array}$ & & $\mathrm{V}$ & $\begin{array}{l}\mathrm{V} \\
\mathrm{V}\end{array}$ & V & V & V & & & \\
\hline $\begin{array}{l}\text { Diergezondheid } \\
-\quad \text { E.Coli }\end{array}$ & & $\mathrm{V}$ & & & & & v & & \\
\hline $\begin{array}{cl}\text { Pikkerij } & \\
- & \text { Kannibalisme } \\
- & \text { Verenpikken }\end{array}$ & v & & & & v & & & V & \\
\hline Kamafwijkingen & & & & & & & & & \\
\hline Darmgezondheid & & & & & & & & & \\
\hline Uitval & V & V & V & & V & V & V & & V \\
\hline Lichaamsgewicht & V & & & $\mathrm{v}$ & v & $\mathrm{V}$ & & & \\
\hline Voer- en wateropname & v & v & & & V & & & & \\
\hline Eiproductie & & V & $?$ & & & & & & $\mathrm{~V}$ \\
\hline Buitennesteieren (BNE) & & V & & & & & & & \\
\hline
\end{tabular}

\begin{tabular}{|c|c|c|c|c|c|c|c|c|c|}
\hline $\begin{array}{l}\text { Stalklimaat } \\
\text { indicatoren }\end{array}$ & 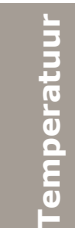 & 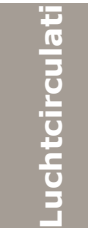 & ${ }_{a}^{*}$ & 8 & 폴 & $\begin{array}{l}\text { "ᄒ } \\
\text { औे }\end{array}$ & 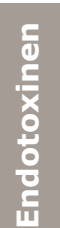 & 릉 & 흘 \\
\hline Vogelmijt & $\mathrm{V}$ & & V & & & & & & \\
\hline Parasieten & V & & V & & & & & & \\
\hline $\begin{array}{l}\text { Hokbevuiling } \\
-\quad \text { Nat strooisel }\end{array}$ & & V & V & & & & & & \\
\hline$m^{3}$ per kip & & & & & & V & & & \\
\hline $\mathrm{m}^{2}$ per kip & & & & & & $\mathrm{V}$ & & & \\
\hline
\end{tabular}

$\mathrm{S}=$ signaalindicator $\mathrm{V}=$ vervolgindicator

* RV kan niet los gezien worden van temperatuur en luchtbeweging 


\subsection{Mogelijke aanpak controle stalklimaat}

Om een mogelijk schadelijk effect van het klimaat op de dieren vast te stellen, dient allereerst naar de dieren zelf gekeken te worden. Aan de hand van een aantal gedragswaarnemingen en dierbeoordelingen kan vastgesteld worden of er mogelijk een acuut of structureel klimaatprobleem is. Bij plotselinge hoge uitval zal het zeer waarschijnlijk gaan om een acuut probleem, maar bij de meeste indicatoren is dat niet direct aan te geven. Zo kan het bij ademhalingsproblemen om een structureel probleem, dat op een bepaald moment tot uiting komt, maar het kan ook een acuut probleem zijn.

De aanwijzingen die de dierindicatoren geven met betrekking tot waar mogelijke knelpunten kunnen liggen ten aanzien van het klimaat, worden gebruikt om gericht metingen aan die klimaatfactoren uit te voeren. Indien de dierindicatoren geen aanleiding geven tot nadere inspectie van het klimaat, kunnen klimaatmetingen achterwege blijven.

\subsubsection{Protocol dierindicatoren}

Op verschillende plaatsen in de stal worden waarnemingen aan de dieren gedaan. Daarbij is van belang om een brede spreiding te hebben van de te beoordelen plaatsen:

- Voorin de stal, links, midden en rechts

- Halverwege de stal, links, midden en rechts

- Achterin de stal, links, midden en rechts

- Bij uitloopopeningen

- $\quad$ Bovenop het systeem

- $\quad$ Onder het systeem

- In het systeem

Om deze plaatsen te bekijken kan een looproute gevolgd worden, waarbij men aan één kant van de stal naar achteren loopt, in het midden terug loopt en vervolgens aan de andere kant weer naar achteren loopt. Bij zeer brede of complexe stallen kan een extra gang mee worden genomen. Deze methode is gevalideerd voor vleeskuikens (BenSassi et al. 2018).

Tijdens het lopen door de stal wordt het aantal dieren geteld en genoteerd dat gedrag vertoont dat kan duiden op een klimaatprobleem. Idealiter zijn dat de volgende gedragingen:

\begin{tabular}{|l|l|l|}
\hline Waargenomen diergedrag & Indicatief voor & Controle klimaatfactoren \\
\hline Huddling & Kou & Temperatuur \\
\hline Hijgen & $\begin{array}{l}\text { Warmte, combinatie warmte }+ \\
\text { hoge } \mathrm{RV}, \text { hoog } \mathrm{CO}_{2} \text {-gehalte }\end{array}$ & $\begin{array}{l}\text { Temperatuur, } \mathrm{RV}, \\
\text { luchtcirculatie, } \mathrm{CO}_{2}\end{array}$ \\
\hline Vleugels spreiden & Warmte & Temperatuur, $\mathrm{RV}$ \\
\hline Happen naar adem & Ademhalingsproblemen & Luchtcirculatie, $\mathrm{CO}_{2}, \mathrm{NH}_{3}$, stof \\
\hline Hoesten, proesten & Ademhalingsproblemen & Luchtcirculatie, $\mathrm{CO}_{2}, \mathrm{NH}_{3}$, stof \\
\hline Ogen dichtknijpen & Hoog $\mathrm{NH}_{3}$-gehalte & $\mathrm{NH}_{3}$ \\
\hline $\begin{array}{l}\text { Hoofdschudden (bij plotselinge } \\
\text { blootstelling) }\end{array}$ & Hoog $\mathrm{CO}_{2}$-gehalte & $\mathrm{CO}_{2}$ \\
\hline Spartelen & $\begin{array}{l}\text { Hoog } \mathrm{NH}_{3} \text {-gehalte, hoog } \mathrm{CO}_{2-}- \\
\text { gehalte }\end{array}$ & $\mathrm{NH}_{3}, \mathrm{CO}_{2}$ \\
\hline
\end{tabular}

Een aantal van de genoemde gedragingen kan tegelijk vertoond worden, bijvoorbeeld hijgen en vleugels spreiden. Om die redenen wordt het aantal afwijkende dieren genoteerd. Op de scorelijst wordt dan per groep geturfd. De volgende groepen worden daarbij onderkend:

- $\quad$ Te koud (huddling)

- Te warm (hijgen, vleugels spreiden)

- Slechte luchtcondities (happen naar adem, hoesten, proesten, ogen dichtknijpen, hoofdschudden, spartelen)

Een voorbeeld van een mogelijk scoreformulier staat in bijlage 1.

Tijdens het lopen door de stal worden ook dieren met zichtbare exterieurproblemen genoteerd. Daarbij worden de volgende aspecten beoordeeld: 


\begin{tabular}{|c|c|c|}
\hline Waargenomen dierfactor & Indicatief voor & Controle klimaatfactoren \\
\hline Vuile borstveren & Nat strooisel & Ventilatie, luchtcirculatie, RV \\
\hline Vuile kont & Darmproblemen & RV, luchtcirculatie \\
\hline $\begin{array}{l}\text { Oog-beoordeling } \\
\begin{aligned}- & \text { Keratoconjunctivitis } \\
- & \text { Oogaandoeningen }\end{aligned}\end{array}$ & Hoog $\mathrm{NH}_{3}$-gehalte & $\mathrm{NH}_{3}$ \\
\hline Voetzooldermatitis & Nat strooisel & Ventilatie, luchtcirculatie \\
\hline $\begin{array}{l}\text { Kamafwijking: zeer bleke } \\
\text { kammen }\end{array}$ & $\begin{array}{l}\text { Langdurige hittestress, } \\
\text { vogelmijtbesmetting }\end{array}$ & $\begin{array}{l}\text { Temperatuur, RV, } \\
\text { luchtcirculatie }\end{array}$ \\
\hline
\end{tabular}

Voor wat betreft voetzooldermatitis is dit een probleem, omdat dit alleen te zien is als dieren opgepakt worden. Indien het strooisel een normale consistentie heeft, kan deze beoordeling achterwege blijven. Indien het strooisel nat is of uit grote dichte koeken bestaat, kunnen steekproefsgewijs dieren opgepakt worden.

Tijdens het lopen door de stal kunnen de onderstaande factoren opvallen:

\begin{tabular}{|l|l|l|}
\hline Waargenomen factor & Indicatief voor & Controle klimaatfactoren \\
\hline $\begin{array}{l}\text { Open plekken waar geen } \\
\text { dieren zitten }\end{array}$ & Kou, tocht & $\begin{array}{l}\text { Temperatuur, } \mathrm{RV}, \\
\text { luchtcirculatie }\end{array}$ \\
\hline Schrikachtigheid, stress & $\begin{array}{l}\text { Laag lichtniveau, hoog } \\
\text { geluidsniveau, pikkerij }\end{array}$ & Lichtniveau, geluidsniveau \\
\hline Vermijdingsreactie & $\begin{array}{l}\text { Hoog } \mathrm{NH}_{3} \text {-gehalte, hoog } \mathrm{CO}_{2-}- \\
\text { gehalte }\end{array}$ & $\mathrm{NH}_{3}, \mathrm{CO}_{2}$ \\
\hline Buitennesteieren (BNE) & Tocht & Luchtcirculatie \\
\hline
\end{tabular}

Een schrikreactie in een koppel leghennen is niet abnormaal. Echter, indien het koppel bovenmatig schrikachtig is, kan dit aanleiding zijn om de aangegeven klimaatfactoren nader te onderzoeken. Buitennesteieren zijn ook een normaal verschijnsel in een legstal, maar kunnen door het aantal en de plaats waar ze liggen een aanwijzing zijn voor bijvoorbeeld een probleem met tocht in de nesten.

\subsubsection{Registratie overige kengetallen}

Vervolgens zijn er een aantal technische kengetallen die een aanwijzing kunnen zijn voor een suboptimaal klimaat, zonder dat er aan het uiterlijk van de dieren iets waar te nemen valt. Uitval is uiteraard wel waarneembaar, maar is een van dierkenmerken die altijd gecheckt dient te worden, omdat het ook een eerste aanwijzing van (structurele) problemen kan zijn. Zeker indien er informatie is over de uitvalsoorzaken kan dit een duidelijk handvat zijn. De overige kengetallen kunnen gecheckt worden als de gedragswaarnemingen daartoe aanleiding geven.

\begin{tabular}{|l|l|l|}
\hline Technisch kengetal & Indicatief voor & Controle klimaatfactoren \\
\hline Hoge uitval & Suboptimale diergezondheid & $\begin{array}{l}\text { Temperatuur, luchtcirculatie, } \\
\mathrm{NH}_{3} \text {, stof, geluidsniveau }\end{array}$ \\
\hline Eiproductie & $\begin{array}{l}\text { Langdurige warmte, langdurig } \\
\text { hoog geluidsniveau }\end{array}$ & $\begin{array}{l}\text { Temperatuur, luchtcirculatie, } \\
\mathrm{NH}_{3} \text {, geluid }\end{array}$ \\
\hline Voeropname & Warmte, koude & $\begin{array}{l}\text { Temperatuur, luchtcirculatie, } \\
\mathrm{NH}_{3}\end{array}$ \\
\hline Wateropname & Warmte & $\begin{array}{l}\text { Temperatuur, luchtcirculatie, } \\
\mathrm{NH}_{3}\end{array}$ \\
\hline
\end{tabular}

Tenslotte zijn er een aantal stalindicatoren, die ofwel indicatief kunnen zijn voor klimaatproblemen ofwel een invloed kunnen hebben op deze problemen. 


\begin{tabular}{|l|l|l|}
\hline Stalindicator & Indicatief voor & Controle klimaatfactoren \\
\hline Nat strooisel & $\begin{array}{l}\text { Vochtig stalklimaat, slechte } \\
\text { ventilatie }\end{array}$ & $\begin{array}{l}\text { Temperatuur, luchtcirculatie, } \\
\text { RV }\end{array}$ \\
\hline Parasieten & $\begin{array}{l}\text { In warme, vochtige omgeving } \\
\text { snellere voortplanting }\end{array}$ & \begin{tabular}{l} 
Temperatuur, RV \\
\hline $\mathrm{m}^{3}$ per kip
\end{tabular} \\
$\begin{array}{l}\text { Minder } \mathrm{m}^{3} \text { per dier geeft eerder } \\
\text { klimaatproblemen }\end{array}$ & $\begin{array}{l}\text { Wellicht uitgaan van kleinere } \\
\text { bandbreedte per } \\
\text { klimaatfactor?* }\end{array}$ \\
\hline $\mathrm{m}^{2}$ per kip & $\begin{array}{l}\text { Minder } \mathrm{m}^{2} \text { geeft hennen minder } \\
\text { mogelijkheden om naar een plek } \\
\text { met betere } \\
\text { klimaatomstandigheden te gaan }\end{array}$ & $\begin{array}{l}\text { Wellicht uitgaan van kleinere } \\
\text { bandbreedte per } \\
\text { klimaatfactor?* }\end{array}$ \\
\hline
\end{tabular}

* per klimaatfactor zal doorgaans een boven- en ondergrens zijn, waarbinnen het dier zich kan aanpassen aan de omstandigheden en het dierenwelzijn nog gegarandeerd is. Doordat er bij een hogere bezetting (dus minder $\mathrm{m}^{3}$ of $\mathrm{m}^{2}$ per dier) minder mogelijkheden zijn voor het dier om zich aan te passen, moten deze grenzen wellicht wat strakker gesteld worden, omdat de waarden eerder limiterend voor het dier worden en het welzijn daardoor in het gedrang kan komen.

\subsubsection{Klimaatmetingen}

Doorgaans kan uit de klimaatcomputer de actuele stand van zaken gehaald worden voor wat betreft staltemperatuur en RV. Daaruit kan worden afgeleid of de temperatuur binnen de voor het dier acceptabele grenzen ligt. Bij extreme buitenttemperaturen zal dit wellicht niet het geval zijn. Belangrijk is dan om te controleren welke maatregelen de pluimveehouder getroffen heeft om de omstandigheden voor de dieren zo goed mogelijk te maken. Te denken valt dan b.v. aan maatregelen zoals:

- $\quad$ bij zeer warme omstandigheden: water sproeien op het dak, extra luchtbeweging creëren m.b.v. ventilatoren of het open zetten van deuren, evt. additionele voerbeurten in minder warme perioden.

- Bij koude: minder uitloopopeningen openen, tocht verminderen door het plaatsen van een schot o.i.d.

Metingen aan $\mathrm{NH}_{3}$ kunnen met behulp van speciale apparatuur verricht worden. Deze dienen dan volgens een vast protocol uitgevoerd te worden, waarbij met name metingen direct boven strooisel roosteroppervlakten van belang zijn. Hieronder bevindt zich doorgaans de grootste bron van emissie, de mest. Met name systemen met een mestput kunnen een hoge $\mathrm{NH}_{3}$-concentratie direct boven de erboven gelegen roosters hebben.

Voor stofmetingen zijn zeer geavanceerde metingen nodig om een zinvolle conclusie te kunnen trekken. Dit lijkt vooralsnog met de huidige kennis en beschikbare apparatuur nog niet uitvoerbaar.

Geluidsmetingen zijn mogelijk, maar er is nog erg weinig bekend over het maximaal aantal decibel en mogelijke aversieve effecten van pieken in geluid. 
In onderstaande tabel staan de klimaatfactoren die redelijkerwijs zouden kunnen worden gemeten of afgelezen uit de klimaatcomputer.

\begin{tabular}{|c|c|c|}
\hline Klimaatfactor & Meting & Aandachtspunt \\
\hline Temperatuur & $\begin{array}{l}\text { Temperatuur via klimaatcomputer of } \\
\text { eigen metingen in de stal }\end{array}$ & $\begin{array}{l}\text { Temperatuur op zich zegt niet veel, hoe het dier deze } \\
\text { ervaart hangt mede af van RV en luchtsnelheid }\end{array}$ \\
\hline $\begin{array}{l}\text { Relatieve } \\
\text { luchtvochtigheid }\end{array}$ & $\begin{array}{l}\text { RV via klimaatcomputer of eigen } \\
\text { metingen in de stal }\end{array}$ & $\begin{array}{l}\text { RV kan niet los gezien worden van temperatuur en } \\
\text { luchtbeweging }\end{array}$ \\
\hline $\mathrm{CO}_{2}$ & $\mathrm{CO}_{2}$-concentratie in stallucht & $\begin{array}{l}\mathrm{CO}_{2} \text { is vrij eenvoudig te meten, dus dit is beter dan te } \\
\text { trachten iets aan de dieren af te leiden }\end{array}$ \\
\hline $\mathrm{NH}_{3}$ & $\begin{array}{l}\text { Puntmetingen, b.v. op kiphoogte } \\
\text { boven de beun. }\end{array}$ & $\begin{array}{l}\mathrm{NH}_{3} \text { zal vooral hoog zijn bij lage ventilatieniveaus in de } \\
\text { koude jaargetijden }\end{array}$ \\
\hline Lichtmeting & $\begin{array}{l}\text { Luxmeter, beter is een Galliluxmeter, } \\
\text { op ooghoogte tussen lichtbronnen in } \\
\text { op meerdere plaatsen }\end{array}$ & $\begin{array}{l}\text { Bij licht spelen vele aspecten een rol: lichtsterkte, } \\
\text { lichtkleur en -spectrum, lichtflikkeringen }\end{array}$ \\
\hline Geluid & Decibel & Er is nog weinig bekend over geluidsinvloeden \\
\hline
\end{tabular}

\subsubsection{Overige bepalingen}

Directe metingen geven nog geen inzicht in een mogelijke langdurige blootstelling aan suboptimale klimaatomstandigheden. Daarvoor zal indien mogelijk de computergegevens over de afgelopen week of weken geraadpleegd moeten worden. Indien dit niet mogelijk is, kan de voer- en wateropname en eiproductie over de afgelopen week of weken bekeken worden. Ook informatie over uitval, medicijngebruik en/of specifieke managementmaatregelen geven inzicht.

Bij het rondlopen in de stal dient goed gekeken te worden naar het strooisel. Bij een slecht klimaat zullen hierin koeken komen of zullen bepaalde oppervlakten zelfs helemaal vastgekoekt raken.

Controles die uitgevoerd kunnen worden:

- Betreft het de gehele stal of is het plaatselijk (b.v. alleen rondom uitloopopeningen)

- Zijn er tekenen dat de pluimveehouder het probleem probeert op te lossen (strooisel losgetrokken, bijgestrooid)

- $\quad$ Betreft het droge koeken of zijn de koeken drassig (in dat laatste geval kunnen er eerder voetzoolproblemen ontstaan)

- Kan het strooisel tot een bal worden geknepen die kort heel blijft, of valt het direct weer rul uit elkaar

In het geval van grote oppervlakten koeken en/of grote plekken nat strooisel kunnen in de buurt hiervan steekproefsgewijs dieren opgepakt worden en gecontroleerd op mogelijke voetzoolproblemen. 


\section{$4 \quad$ Conclusies en aanbevelingen}

Op basis van literatuuronderzoek en de brainstormsessie met experts kan gesteld worden dat er een beperkt aantal signaalindicatoren is om te controleren of het klimaat zodanig is dat het welzijn van de dieren niet geschaad is. Aan de hand van de beschikbare kennis is een concept protocol opgesteld. Niet duidelijk is of dit protocol onderscheidend genoeg zal zijn om daadwerkelijk welzijnsproblemen te kunnen vaststellen. Drempelwaardes, zoals bijvoorbeeld hoeveel dieren met afwijkend gedrag acceptabel zijn, zijn ook onbekend. Het verdient dan ook aanbeveling om het protocol nader in de praktijk uit te testen en zo mogelijk door te ontwikkelen. Gedacht kan dan worden aan het uittesten van het protocol volgens een stappenplan:

a) Uittesten van het protocol door steeds 2 controleurs samen met een onderzoeker op 2-5 bedrijven in een periode waarin extreme klimaatomstandigheden te verwachten kunnen zijn (hoge of juist lage buitentemperaturen, hoge vochtigheid).

b) Evaluatie van de bevindingen in een groep controleurs, samen met onderzoekers en experts.

c) Desgewenst gericht onderzoek naar informatie rondom enkele knelpunten of vraagtekens.

d) Aanscherping van de protocollen.

De stappen a $\mathrm{t} / \mathrm{m} \mathrm{d}$ zouden herhaald kunnen worden totdat een goed werkbaar protocol verkregen is of totdat er geconcludeerd moet worden dat er geen verbetering meer haalbaar is. 


\section{Literatuur}

Advieswaarden Gezondheidsraad, zie bv : https://www.ser.nl/nl/thema/arbeidsomstandigheden/grenswaarden-werkplek/Grenswaarden

Aerts, J. M., C. M. Wathes, and D. Berckmans. 2004. Environmental management for laying hens. Edited by G. Perry. Vol. 27. Welfare of the Laying Hen. Cambridge: Cabi Publishing.

Al-Saffar, A. A., and S. P. Rose. 2002. Ambient temperature and the egg laying characteristics of laying fowl. World's Poultry Science Journal 58 (3): 317-331. http://dx.doi.org/Doi: 10.1079/wps20020025.

Amer, A., H. Pingel, J. Hillig, M. Soltan, and E. Von Borell. 2004. Impact of atmospheric ammonia on laying performance and egg shell strength of hens housed in climatic chambers. Archiv fur Geflugelkunde 68 (3): 120-124.

Anderson, D. P., C. W. Beard, and R. P. Hanson. 1966. Influences of poultry house dust, ammonia and carbon dioxide on the resistance of chickens to Newcastle disease virus. Avian Diseases 10: 177-188.

Arieli, A., A. Meltzer, and A. Berman. 1979. Seasonal acclimatisation in the hen. British Poultry Science 20 (6): 505-513. http://dx.doi.org/10.1080/00071667908416614.

Arieli, A., Meltzer, A. and Berman, A. 1980. The thermoneutral temperature zone and seasonal acclimatisation in the hen. British Poultry Science 21 (6): 471-478. http://dx.doi.org/10.1080/00071668008416699.

Baxter, M., N. Joseph, V. R. Osborne, and G. Y. Bédécarrats. 2014. Red light is necessary to activate the reproductive axis in chickens independently of the retina of the eye. Poultry Science 93 (5): 1289-1297. http://dx.doi.org/10.3382/ps.2013-03799.

BenSassi, N., X. Averós, and I. Estevez. 2018. The potential of the transect method for early detection of welfare problems in broiler chickens. Poultry Science 98 (2): 522-532. http://dx.doi.org/10.3382/ps/pey374.

Cambra-López, M., T. Hermosilla, T. L. H. Lai, A. J. A. Aarnink, and N. W. M. Ogink. 2011. Particulate matter emitted from poultry and pig houses: source identification and quantification.

Transactions of the ASABE / American Society of Agricultural and Biological Engineers 54 (2): 629-642.

Campo, J. L., M. T. Prieto, and S. G. Dávila. 2008. Effects of Housing System and Cold Stress on Heterophil-to-Lymphocyte Ratio, Fluctuating Asymmetry, and Tonic Immobility Duration of Chickens. Poultry Science 87 (4): 621-626. http://dx.doi.org/10.3382/ps.2007-00466.

Chai, L., J. Q. Ni, C. A. Diehl, I. Kilic, A. J. Heber, Y. Chen, E. L. Cortus, et al. 2012. Ventilation rates in large commercial layer hen houses with two-year continuous monitoring. British Poultry Science 53 (1): 19-31. http://dx.doi.org/10.1080/00071668.2011.643766.

Chepete, H. J., and H. Xin. 2004. Ventilation rates of a laying hen house based on new vs. old heat and moisture production data. Applied Engineering in Agriculture 20 (6): 835-842.

David, B., R. Oppermann Moe, V. Michel, V. Lund, and C. Mejdell. 2015. Air Quality in Alternative Housing Systems May Have an Impact on Laying Hen Welfare. Part I-Dust. Animals : an Open Access Journal from MDPI 5 (3): 495-511. http://dx.doi.org/10.3390/ani5030368.

Dayyani, N., and H. Bakhtiari. 2013. Heat Stress in Poultry: Background and Affective Factors. International Journal of Advanced Biological and Biomedical Research 1 (11): 1409-1413.

de Jong, I., C. Berg, A. Butterworth, and I. Estevéz. 2012. Scientific report updating the EFSA opinions on the welfare of broilers and broiler breeders. EFSA Supporting Publications 9 (6:EN-295): 116. http://dx.doi.org/10.2903/sp.efsa.2012.EN-295.

E.U., 2007. Council Directive 2007/43/EC of 28 June laying down minimum rules for the protection of chickens kept for meat production. . Official Journal L 182: 19-28.

E.U., 2008. Richtlijn 2008/50/EG van het Europees Parlement en de Raad van 20 mei 2008 betreffende de luchtkwaliteit en schonere lucht voor Europa. OJ L 152, 11.6.2008, p. 1-44

EFSA. 2005. Opinion of the Scientific Panel on Animal Health and Welfare (AHAW) on a request from the Commission related to the welfare aspects of various systems of keeping laying hens. EFSA Journal 3 (197): 1-23. 
Gurdil, G. A. K. 2009. Numerical Simulation of Natural Ventilation Rates in Laying Hen Houses. Journal of Animal and Veterinary Advances 8 (4): 624-629.

Heerkens, J. L. T., E. Delezie, T. B. Rodenburg, I. Kempen, J. Zoons, B. Ampe, and F. A. M. Tuyttens. 2016. Risk factors associated with keel bone and foot pad disorders in laying hens housed in aviary systems. Poultry Science 95 (3): 482-488. http://dx.doi.org/10.3382/ps/pev339.

Hoeksma, P., A. J. A. Aarnink, and N. W. M. Ogink. 2015. Effect of temperature and relative humidity on the survival of airborne bacteria = Effect van temperatuur en relatieve luchtvochtig-heid op de overleving van bacteriën in de lucht. Wageningen: Wageningen UR Livestock Research.

Hofmans, F., 2018. Handhaving van open normen rondom dierenwelzijn; De bepaling van signaalindicatoren voor een ontoereikend stalklimaat op legkipbedrijven. Een systematische literatuurstudie. $45 \mathrm{p}$.

Holik, V. 2009. Management of laying hens to minimize heat stress. Lohmann Information 44 (1): 1629.

Hooper, P., and S. A. Richards. 1991. Interaction of operant behaviour and autonomic thermoregulation in the domestic fowl. British Poultry Science 32 (5): 929-938. http://dx.doi.org/10.1080/00071669108417419.

Huneau-Salaun, A., S. Le Bouquin, V. Bex-Capelle, D. Huonnic, L. Balaine, M. T. Guillam, F. Squizani, C. Segala, and V. Michel. 2011. Endotoxin concentration in poultry houses for laying hens kept in cages or in alternative housing systems. British Poultry Science 52 (5): 523-530. http://dx.doi.org/10.1080/00071668.2011.617728.

Jones, E. K. M., C. M. Wathes, and A. J. F. Webster. 2005. Avoidance of atmospheric ammonia by domestic fowl and the effect of early experience. Applied Animal Behaviour Science 90 (3): 293 308. http://dx.doi.org/https://doi.org/10.1016/j.applanim.2004.08.009.

Kampen, M. V., B. W. Mitchell, and H. S. Siegel. 1979. Thermoneutral zone of chickens as determined by measuring heat production, respiration rate, and electromyographic and electroencephalographic activity in light and dark environments and changing ambient temperatures. The Journal of Agricultural Science 92 (1): 219-226. http://dx.doi.org/Doi: 10.1017/s0021859600060664.

Karaman, S., S. Tarhan, and G. Ergunes. 2007. Analysis of indoor climatic data to assess the heat stress of laying hens. International Journal of Natural and Engineering Sciences 1 (2): 65-68.

Kilpinen, O., A. Roepstorff, A. Permin, G. Nørgaard-Nielsen, L. G. Lawson, and H. B. Simonsen. 2005. Influence of Dermanyssus gallinae and Ascaridia galli infections on behaviour and health of laying hens (Gallus gallus domesticus). British Poultry Science 46 (1): 26-34. http://dx.doi.org/10.1080/00071660400023839.

Klimaatplatform Pluimvee, zie http://www.wageningenur.nl/nl/show/Klimaatplatforms-Varkens-enPluimveehouderij.htm

Kowalski, A., and R. Sokol. 2009. Influence of Dermanyssus gallinae (poultry red mite) invasion on the plasma levels of corticosterone, catecholamines and proteins in layer hens. Polish Journal of Veterinary Sciences 12 (2): 231-235.

Kristensen, H. H., L. R. Burgess, T. G. H. Demmers, and C. M. Wathes. 2000. The preferences of laying hens for different concentrations of atmospheric ammonia. Applied Animal Behaviour Science 68 (4): 307-318. http://dx.doi.org/https://doi.org/10.1016/S0168-1591(00)00110-6.

Kristensen, H. H., and C. M. Wathes. 2000. Ammonia and poultry welfare: a review. World's Poultry Science Journal 56 (3): 235-245. http://dx.doi.org/Doi: 10.1079/wps20000018.

Le Bouquin, S., A. Huneau-Salaun, D. Huonnic, L. Balaine, S. Martin, and V. Michel. 2013. Aerial dust concentration in cage-housed, floor-housed, and aviary facilities for laying hens. Poultry Science 92 (11): 2827-33. http://dx.doi.org/10.3382/ps.2013-03032.

Lewis, P., and T. Morris. 2006. Poultry Lighting : The Theory and Practice. Andover: Northcot.

Li, T., D. Troilo, A. Glasser, and H. C. Howland. 1995. Constant light produces severe corneal flattening and hyperopia in chickens. Vision Research 35 (9): 1203-1209. http://dx.doi.org/http://dx.doi.org/10.1016/0042-6989(94)00231-A.

Lisney, T. J., B. Ekesten, R. Tauson, O. Håstad, and A. Ödeen. 2012. Using electroretinograms to assess flicker fusion frequency in domestic hens Gallus gallus domesticus. Vision Research 62 (0): 125-133. http://dx.doi.org/http://dx.doi.org/10.1016/j.visres.2012.04.002.

McKeegan, D. E. F., F. S. Smith, T. G. M. Demmers, C. M. Wathes, and R. B. Jones. 2005. Behavioral correlates of olfactory and trigeminal gaseous stimulation in chickens, Gallus domesticus. 
Physiology \& Behavior 84 (5): 761-768.

http://dx.doi.org/https://doi.org/10.1016/j.physbeh.2005.03.005.

Meltzer, A., G. Goodman, and J. Fistool. 1982. Thermoneutral zone and resting metabolic rate of growing white leghorn-type chickens. British Poultry Science 23 (5): 383-391.

http://dx.doi.org/10.1080/00071688208447972.

Moinard, C., P. Statham, M. J. Haskell, C. McCorquodale, R. B. Jones, and P. R. Green. 2004. Accuracy of laying hens in jumping upwards and downwards between perches in different light environments. Applied Animal Behaviour Science 85 (1-2): 77-92.

http://dx.doi.org/10.1016/j.applanim.2003.08.008.

Naseem, S., and A. J. King. 2018. Ammonia production in poultry houses can affect health of humans, birds, and the environment-techniques for its reduction during poultry production. Environmental Science and Pollution Research 25 (16): 15269-15293. http://dx.doi.org/10.1007/s11356-018-2018-y.

Niekerk, T. G. C. M. v., H. H. Ellen, and A. Winkel. 2015. Licht op licht: licht en verlichting in de pluimveehouderij in relatie tot beschadigend pikgedrag. In Livestock Research rapport

O'Connor, E. A., M. O. Parker, E. L. Davey, H. Grist, R. C. Owen, B. Szladovits, T. G. M. Demmers, C. M. Wathes, and S. M. Abeyesinghe. 2011. Effect of low light and high noise on behavioural activity, physiological indicators of stress and production in laying hens. British Poultry Science 52 (6): 666-674. http://dx.doi.org/10.1080/00071668.2011.639342.

Pedersen, S., H. Takai, J. O. Johnsen, J. H. M. Metz, P. W. G. Groot Koerkamp, G. H. Uenk, V. R. Phillips, et al. 1998. A Comparison of Three Balance Methods for Calculating Ventilation Rates in Livestock Buildings. Journal of Agricultural Engineering Research 70 (1): 25-37. http://dx.doi.org/https://doi.org/10.1006/jaer.1997.0276.

Reece, F., and B. Lott. 1980. Effect of carbon dioxide on broiler chicken performance. Poultry science 59 (11): 2400-2402.

Reuvekamp, B. F. J., and T. G. C. M. v. Niekerk. 2010. Cruciale rol voor UV. Pluimveehouderij, 15 oktober 2010, 26-27. (accessed

RIVM, 2013. Dossier 'Fijn stof', hoofdstuk 7, 'Regelgeving'. Versie 1 (c) RIVM, Bilthoven, januari 2013.

Ruzal, M., D. Shinder, I. Malka, and S. Yahav. 2011. Ventilation plays an important role in hens' egg production at high ambient temperature. Poultry Science 90 (4): 856-862. http://dx.doi.org/10.3382/ps.2010-00993.

Sparagano, O., A. Pavlićević, T. Murano, A. Camarda, H. Sahibi, O. Kilpinen, M. Mul, et al. 2009. Prevalence and key figures for the poultry red mite Dermanyssus gallinae infections in poultry farm systems. Experimental and Applied Acarology 48 (1-2): 3-10. http://dx.doi.org/10.1007/s10493-008-9233-z.

Spinu, M., and A. A. Degen. 1993. Effect of cold stress on performance and immune responses of Bedouin and white leghorn hens. British Poultry Science 34 (1): 177-185. http://dx.doi.org/10.1080/00071669308417573.

Stokkermans, P., 2017. Sensoren zorgen voor gezonde dieren. Nieuwe Oogst 4 mei 2017. https://www.nieuweoogst.nu/nieuws/2017/05/04/sensoren-zorgen-voor-gezonde-dieren

Voeten, A. C. 2000. Gezond pluimvee : handboek voor de beroepspluimveehouder en sportfokker. Groene reeks. Warnsveld: Terra Zutphen.

Weeks, C. A., S. N. Brown, G. J. Richards, L. J. Wilkins, and T. G. Knowles. 2012. Levels of mortality in hens by end of lay on farm and in transit to slaughter in Great Britain. Veterinary Record 170 (25): 647-+. http://dx.doi.org/10.1136/vr.100728.

Welfare_Quality®. 2009. Welfare Quality ${ }^{\circledR}$ assessment protocol for poultry (broilers, laying hens). Lelystad, Netherlands: Welfare Quality ${ }^{\circledR}$ Consortium.

Wet Milieubeheer, 2019. Wet milieubeheer; Wet van 13 juni 1979, houdende regelen met betrekking tot een aantal algemene onderwerpen op het gebied van de milieuhygiëne, Geldend van 14-112019 (geraadpleegd 5-12-2019). https://wetten.overheid.nl/BWBR0003245/2019-1114/\#Hoofdstuk22

Winkel, A. 2018. Fijnstof is geen fijn stofje. Brochure. Wageningen: Wageningen Livestock Research. Winkel, A., J. J. Erbrink, I. M. Wouters, i. Huis, J. W. H. T Veld, D. J. J. Heederik, and N. W. M. Ogink. 2018. Emissies van endotoxinen uit de veehouderij : eindrapport endotoxine metingen $=$ Emissions of endotoxins from animal production: final report on endotoxin measurements. Wageningen: Wageningen Livestock Research. 
Winkel, A., I. M. Wouters, A. J. A. Aarnink, D. J. J. Heederik, and N. W. M. Ogink. 2014. Emissies van endotoxinen uit de veehouderij: een literatuurstudie voor ontwikkeling van een toetsingskader = Emissions of endotoxins from animal production: a literature survey for development of an assessment framework. Wageningen: Wageningen UR Livestock Research.

Xiong, Y., Q.-s. Meng, J. Gao, X.-f. Tang, and H.-f. Zhang. 2017. Effects of relative humidity on animal health and welfare. Journal of Integrative Agriculture 16 (8): 1653-1658. http://dx.doi.org/https://doi.org/10.1016/S2095-3119(16)61532-0.

Zanella, A., G. L. Alborali, M. Bardotti, P. Candotti, P. F. Guadagnini, P. Anna Martino, and M. Stonfer. 2000. Severe Escherichia coli 0111 septicaemia and polyserositis in hens at the start of lay. Avian Pathology 29 (4): 311-317. http://dx.doi.org/10.1080/03079450050118430. 


\section{Bijlage 1 Enkele bepalingen voor leghennen uit Besluit houders van dieren}

\section{Hoofdstuk 1. Algemeen}

\section{§ 1. Algemene bepalingen}

\section{Artikel 1.7. Verzorgen van dieren}

Degene die een dier houdt, draagt er zorg voor dat een dier:

g. voldoende verse lucht of zuurstof krijgt.

\section{Artikel 1.8. Behuizing}

1. Een ruimte waarin een dier wordt gehouden, wordt voldoende verlicht en verduisterd om aan de ethologische en fysiologische behoeften van het dier te voldoen.

\section{Hoofdstuk 2. Houden van dieren voor landbouwdoeleinden}

\section{$\S$ 2. Algemene huisvestings- en verzorgingsnormen}

\section{Artikel 2.5. Verlichting en ventilatie}

1. Onverminderd artikel 1.8 , eerste lid, wordt een dier niet permanent in het duister of in kunstlicht gehouden zonder dat dit voor een passende periode wordt uitgeschakeld en is, indien het beschikbare natuurlijke licht niet voldoende is voor de ethologische en fysiologische behoeften van het dier, in de ruimte waarin het dier wordt gehouden geschikt kunstlicht aanwezig.

2. In een ruimte waarin dieren worden gehouden is voldoende verlichting aanwezig voor een grondige controle van die dieren op elk willekeurig tijdstip

4. De luchtcirculatie, het stofgehalte van de lucht, de temperatuur, de relatieve luchtvochtigheid en de gasconcentraties in de omgeving van het dier zijn niet schadelijk voor het dier.

5. Indien de gezondheid en het welzijn van een dier afhankelijk is van een kunstmatig ventilatiesysteem, is dat voorzien van een passend noodsysteem waarmee voldoende verse lucht kan worden aangevoerd om de gezondheid en het welzijn van het dier te waarborgen als het hoofdsysteem uitvalt.

6. Indien het ventilatiesysteem, bedoeld in het vijfde lid, uitvalt, treedt een alarmsysteem in werking, dat regelmatig wordt getest.

8. De in dit artikel bedoelde apparatuur die noodzakelijk is voor de gezondheid en het welzijn van een dier wordt ten minste eenmaal per dag gecontroleerd.

9. Indien bij de controle, bedoeld in het achtste lid, defecten worden geconstateerd, worden deze onmiddellijk hersteld of, indien herstel niet mogelijk is, worden de nodige maatregelen getroffen om de gezondheid en het welzijn van het dier veilig te stellen. 


\section{§ 6. Houden van pluimvee voor productie}

\section{§ 6.2. Houden van legkippen voor productie}

\section{Artikel 2.73. Algemene eisen huisvesting}

1. Het geluidsniveau wordt zo laag mogelijk gehouden. Aanhoudend of plotseling lawaai wordt vermeden. Constructie, opstelling, onderhoud en werking van ventilatietoestellen, voedermachines of andere apparaten veroorzaken zo weinig mogelijk lawaai.

\section{Artikel 2.75. Verlichting}

1. Er is voldoende goed werkende verlichtingsapparatuur aanwezig voor een grondige inspectie van iedere legkip op elk willekeurig tijdstip.

2. Een stal waarin legkippen zijn ondergebracht is gedurende de lichtperiode zodanig verlicht dat de legkippen elkaar duidelijk kunnen zien, dat zij hun omgeving visueel kunnen verkennen en dat zij hun gebruikelijke activiteiten kunnen ontplooien. In geval van verlichting met daglicht zijn de lichtopeningen zodanig gepositioneerd dat het licht gelijkmatig over de stal en de kooien wordt verdeeld.

3. Per 24 uur is er een ononderbroken duisternisperiode van 8 uur waarin de legkippen kunnen rusten. Bij de vermindering van kunstlicht wordt een periode van halfduister in acht genomen om de legkippen de gelegenheid te geven zonder verwondingen op stok te gaan. 


\section{Bijlage 2 Voorbeeld scoreformulier dierindicatoren}

Tellingen afwijkend gedrag

\begin{tabular}{|l|l|l|l|}
\hline Gangpad & $\begin{array}{l}\text { Te koud } \\
- \text { huddling }\end{array}$ & $\begin{array}{l}\text { Te warm } \\
- \text { hijgen } \\
- \text { vleugels spreiden }\end{array}$ & $\begin{array}{l}\text { Slechte luchtcondities } \\
- \text { happen naar adem } \\
- \text { hoesten/proesten } \\
- \text { ogen dichtknijpen } \\
\text { - hoofdschudden } \\
\text { - spartelen) }\end{array}$ \\
\hline 1 & & & \\
\hline 2 & & & \\
\hline 3 & & & \\
\hline 4 & & & \\
\hline & & & \\
\hline
\end{tabular}

Tellingen afwijkende dieren

\begin{tabular}{|l|l|l|}
\hline $\begin{array}{l}\text { Waargenomen } \\
\text { dierfactor }\end{array}$ & Aantal dieren & $\begin{array}{l}\text { Controle } \\
\text { klimaatfactoren }\end{array}$ \\
\hline Vuile borstveren & Ventilatie, luchtcirculatie \\
\hline Vuile kont & & \\
\hline $\begin{array}{l}\text { Oog-beoordeling } \\
\text { - Keratoconjunctivitis } \\
\text { - Oogaandoeningen }\end{array}$ & \begin{tabular}{l}
$\mathrm{NH}_{3}$ \\
\hline $\begin{array}{l}\text { Voetzooldermatitis } \\
\text { Kamafwijking: zeer bleke } \\
\text { kammen }\end{array}$
\end{tabular} & Ventilatie, luchtcirculatie \\
\hline
\end{tabular}




\section{Tellingen overige factoren}

\begin{tabular}{|l|l|l|}
\hline Waargenomen factor & Aantal keren waargenomen & Controle klimaatfactoren \\
\hline $\begin{array}{l}\text { Open plekken waar geen } \\
\text { dieren zitten }\end{array}$ & & Temperatuur, luchtcirculatie \\
\hline Schrikachtigheid, stress & & Lichtniveau, geluidsniveau \\
\hline Vermijdingsreactie & & $\mathrm{NH}_{3}, \mathrm{CO}_{2}$ \\
\hline Buitennesteieren (BNE) & (meer dan 5 bij elkaar) & Luchtcirculatie \\
\hline
\end{tabular}

\section{Controle technische kengetallen}

\begin{tabular}{|l|l|l|}
\hline Technisch kengetal & $\begin{array}{l}\text { Waarde hoger/lager dan } \\
\text { normaal }\end{array}$ & Controle klimaatfactoren \\
\hline Hoge uitval & & $\begin{array}{l}\text { Temperatuur, luchtcirculatie, } \mathrm{NH}_{3}, \\
\text { stof, geluidsniveau }\end{array}$ \\
\hline Eiproductie & & $\begin{array}{l}\text { Temperatuur, luchtcirculatie, } \\
\text { geluid }\end{array}$ \\
\hline Voeropname & & Temperatuur, luchtcirculatie, $\mathrm{NH}_{3}$ \\
\hline Wateropname & & Temperatuur, luchtcirculatie, $\mathrm{NH}_{3}$ \\
\hline
\end{tabular}




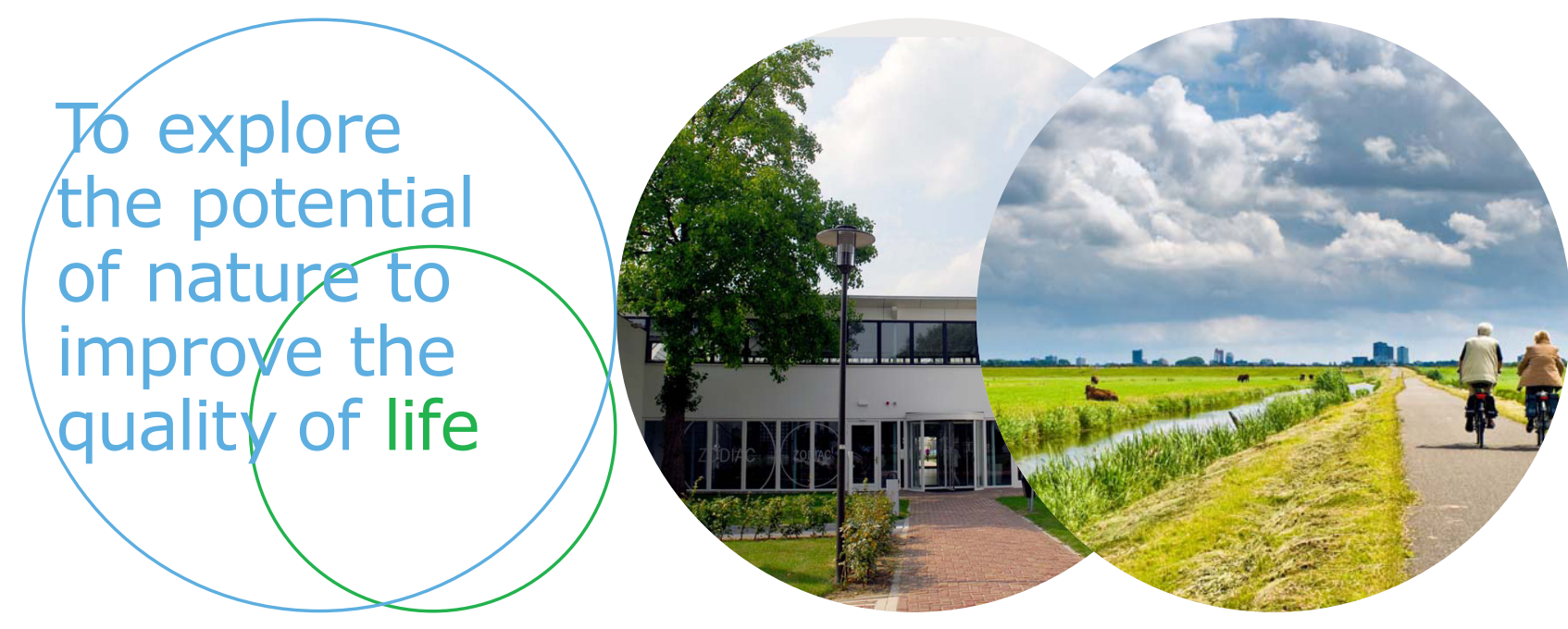

Wageningen Livestock Research Postbus 338

Wageningen Livestock Research ontwikkelt kennis voor een zorgvuldige en $6700 \mathrm{AH}$ Wageningen

T 0317483953

renderende veehouderij, vertaalt deze naar praktijkgerichte oplossingen en innovaties, en zorgt voor doorstroming van deze kennis. Onze wetenschappelijke E info.livestockresearch@wur.nl www.wur.nl/ livestock-research kennis op het gebied van veehouderijsystemen en van voeding, genetica, welzijn en milieu-impact van landbouwhuisdieren integreren we, samen met onze klanten, tot veehouderijconcepten voor de 21 e eeuw.

De missie van Wageningen University \& Research is 'To explore the potential of nature to improve the quality of life'. Binnen Wageningen University \& Research bundelen 9 gespecialiseerde onderzoeksinstituten van Stichting Wageningen Research en Wageningen University hun krachten om bij te dragen aan de oplossing van belangrijke vragen in het domein van gezonde voeding en leefomgeving. Met ongeveer 30 vestigingen, 6.500 medewerkers en 10.000 studenten behoort Wageningen University \& Research wereldwijd tot de aansprekende kennisinstellingen binnen haar domein. De integrale benadering van de vraagstukken en de samenwerking tussen verschillende disciplines vormen het hart van de unieke Wageningen aanpak. 